DIW BERLIN

Discussion Papers

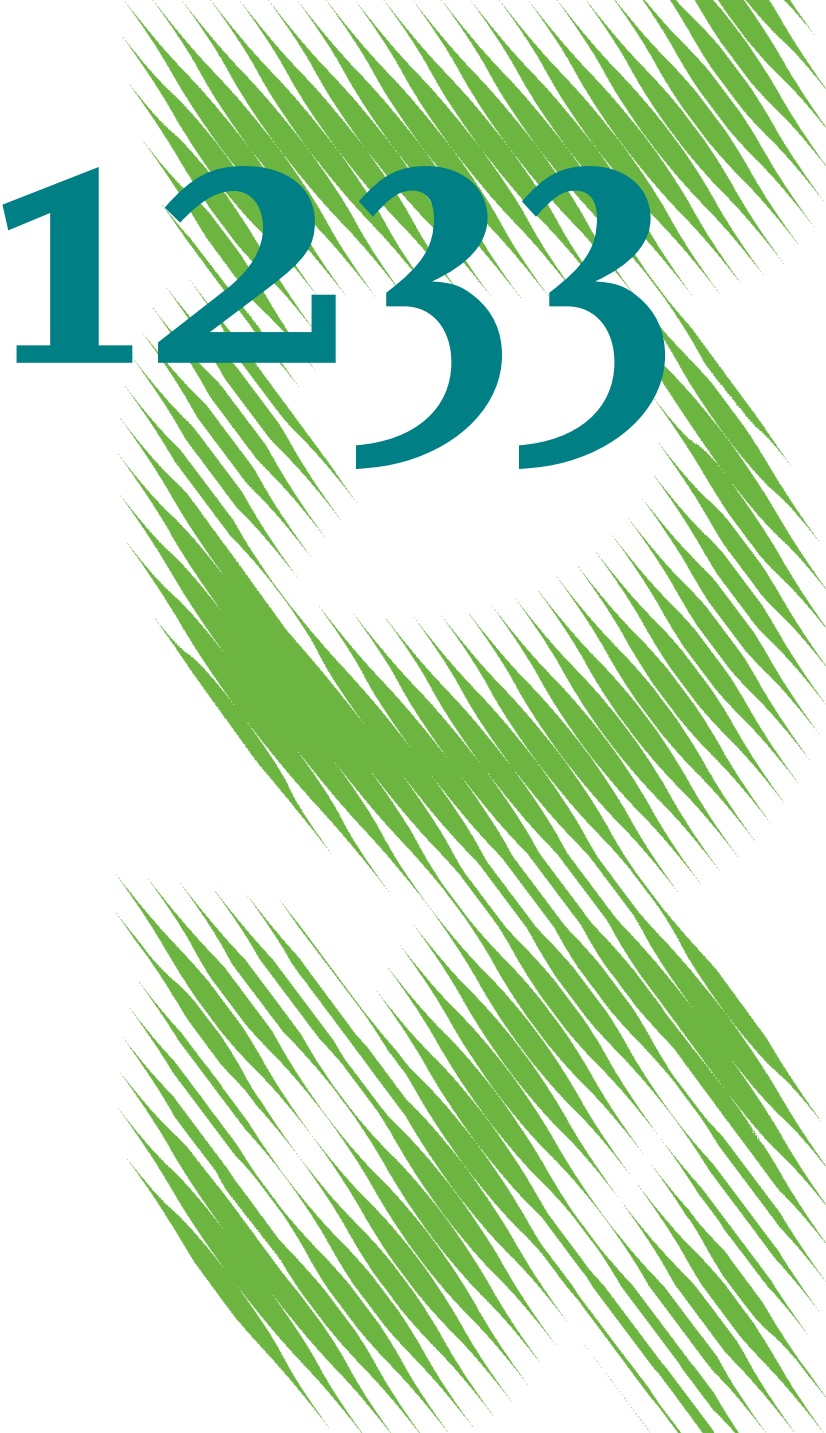

Distributional Impact of the Great Recession on Industry Unemployment for 1976-2011 
Opinions expressed in this paper are those of the author(s) and do not necessarily reflect views of the institute.

IMPRESSUM

(C) DIW Berlin, 2012

DIW Berlin

German Institute for Economic Research

Mohrenstr. 58

10117 Berlin

Tel. $+49(30) 89789-0$

Fax +49 (30) $89789-200$

http://www.diw.de

ISSN print edition $1433-0210$

ISSN electronic edition 1619-4535

Papers can be downloaded free of charge from the DIW Berlin website:

http://www.diw.de/discussionpapers

Discussion Papers of DIW Berlin are indexed in RePEc and SSRN:

http://ideas.repec.org/s/diw/diwwpp.html

http://www.ssrn.com/link/DIW-Berlin-German-Inst-Econ-Res.html 


\title{
Distributional impact of the Great Recession on industry unemployment for 1976-2011*
}

\author{
Yelena Takhtamanova ${ }^{\dagger}$ \\ Federal Reserve Bank of San Francisco \\ Eva Sierminska ${ }^{\ddagger}$ \\ CEPS/INSTEAD, Luxembourg, DIW Berlin and IZA
}

\begin{abstract}
The recession the United States economy entered in December of 2007 is considered to be the most severe downturn the country has experienced since the Great Depression. In this paper we decompose the changes in the unemployment rate by examining worker flows into and out of unemployment during the last four recessions in the United States with a special focus on the industry groups. Since the most recent economic downturn has been triggered by the collapse of the housing market, we are interested in looking at the industries that are most affected by the housing market weakness (such as construction and finance, insurance and real estate). In addition to documenting and comparing industry experiences and industry contributions to the aggregate unemployment rate changes, we attempt to evaluate the relative importance of cyclical and structural forces driving industry-specific unemployment rate changes. This question is of importance to policymakers as cyclical and structural changes call for different policy responses.

We use publicly available data from the Current Population Survey (CPS). Three series are necessary to compute the unemployment inflow and outflow rates by industry: the number of unemployed, the unemployment rate and the number of short-term unemployed (those unemployed for less than 5 weeks). These series for the broadest industry classification are available from BLS, but only from 2000. We obtain data that goes back beyond 2000 and reclassify according the BLS guidelines. Our task is complicated by the change in industry classification of the CPS in 1983 and 2003 and the 1994 re-design of the CPS survey. We extend our data further back and look at a finer disaggregation, which allows us to make comparisons previously not possible.

We find that construction, manufacturing and services were the three industries that contributed the most to the aggregate unemployment rate increase during the most recent downturn. However, the burden of unemployment was not evenly distributed across these industries: while the contribution of construction and manufacturing by far exceeded their share in the labor force, the opposite is the case for services. During the recovery, construction and manufacturing are strong "drivers" of the unemployment rate decline, but services are not. In terms of job flows, the dramatic decline in the job finding probability was the main source of the recessionary unemployment rate increase. In particular, the decline in job finding probability in services, manufacturing, construction and wholesale and retail trade were large contributors. It is the lack of strong recovery in job finding probability that seems to be holding unemployment rate from declining more rapidly during the recovery. Services and public administration stand out as sectors that provided relief in the past recoveries, but are not doing so this time around.
\end{abstract}

Keywords: Unemployment, Worker flows, Job Finding Rate, Separation Rate, Industry, Occupation JEL Codes: J1, J6

\footnotetext{
*We would like to thank Ian Hathaway and David Lang for excellent research assistance on this project.

${ }^{\dagger}$ Federal Reserve Bank of San Francisco, 101 Market Street, MS 1130, San Francisco, CA 94105 USA; e-mail: Yelena.Takhtamanova@sf.frb.org

${ }^{\ddagger}$ CEPS/INSTEAD Research Institute, 3 avenue de la Fonte, L-4363 Esch-sur-Alzette, Luxembourg; e-mail: eva.sierminska@ceps.lu
} 


\section{Introduction}

The recession the United States economy entered in December of 2007 is considered to be the most severe downturn the country has experienced since the Great Depression. The unemployment rate peaked at 10.1 percent in October 2010 - the highest we have seen since the 1982 recession. Adjusted for the change in the labor force demographics, the unemployment rate is actually the highest since 1948 (the beginning of the data availability).

The National Bureau of Economic Analysis (NBER) announced that the recession ended in June 2009. Yet, job losses continued and the anemic job gains that followed have not been enough to significantly bring down the unemployment rate. Overall, the U.S. economy lost over 8.6 million jobs during the period from December 2007 to February 2010. While the private sector recently started adding jobs and and the unemployment rate came down from the peak (in May 2012, it stands at 8.2 percent), a multitude of public and private forecasters as well as prominent policymakers suggest that it will take years for the U.S. labor market to recover (see, for example, a recent testimony of the Fed Chairman Ben Bernanke.) ${ }^{1}$ The dramatic increase in the national unemployment rate during the recession was not equally spread across demographic groups and industries (Autor (2011)). In this project we build upon our previous work, which finds that men, younger workers, the less educated and those from ethnic minorities have been impacted disproportionately more by the downturn (Sierminska and Takhtamanova (2011)) and extend it to examine the impact on industries. We focus on the variation that exists across industries, as some are more affected by the business cycle (construction, manufacturing) than others (services, public administration).

How does this recession compare to other ones? What is the main driving force of rising unemployment? Is it fueled by higher worker inflows into unemployment or decreasing worker outflows? What are the differences across industries? We take a stab at answering these important questions by examining labor market experiences across several industries. First, we decompose changes in the unemployment rate by examining the contribution of each industry to the unemployment rate increase and decline. Next, we examine worker flows into and out of unemployment during the current recession. We focus on the contribution of job finding and separation probability to the aggregate unemployment rate during the recession and to the unemployment rate dynamics during the recovery. Since the most recent economic downturn has been driven by the housing market, we focus our interest on industries directly affected by the housing market weakness such as construction, and FIRE (finance, insurance and real estate). We contribute to the literature by employing industry-specific job finding and separation rates to investigate the increase in the unemployment rate during the recession and the stubbornly high unemployment rate during the recovery. We extend the

\footnotetext{
${ }^{1}$ Bernanke 2011-http://www.federalreserve.gov/newsevents/testimony/bernanke20110209a.htm
} 
existing methodology for decomposing the movements in the aggregate unemployment rate to the industryspecific case.

One question that arises is the extent to which changes in the unemployment rate are driven by structural forces (i.e. sectoral reallocation of workers) versus cyclical ones (lack of jobs in all sectors). Since the onset of the recession, there has been disagreement about the extent of structural changes in the economy. Edmund Phelps maintains that "our economy is damaged by deep structural faults that no stimulus package will address." ${ }^{2}$ On the other hand, Paul Krugman is one of many voices arguing that it is hard to find evidence to support the view of a structural unemployment rise in the US. Policymakers also debate the issue. One can find evidence of such debate among monetary policymakers in reviewing the minutes of Federal Open Market Committee (FOMC) meetings (see, for instance, the minutes from January 25-26, 2011 meeting ${ }^{3}$ ), which reflect that the issues of structural unemployment and the difficulties researchers face measuring certain determinants of structural unemployment in real time received particular attention during the meetings.

Reallocation of workers across sectors takes time and, therefore, structural changes lead to longer unemployment spells (as it might take a long time for workers to acquire skills necessary to move from one sector of the economy to another) and a higher overall unemployment rate. On the other hand, cyclical changes might not lead to long lasting changes in the unemployment rate. For policymakers, in the event that changes are largely cyclical, expansionary fiscal and monetary policy is easier to justify. On the other hand, if the increase in the unemployment rate is mostly structural, policy interventions that help to align workforce skills with job openings are instead more warranted. We contribute to this discussion by presenting additional evidence on the variation of job finding probability across industries. We do not find evidence in support of large structural changes in the US labor market.

\section{Methodology}

Unemployment rates inform us about the share of people in the labor force that are not working but are seeking a job in a given period of time or the probability that a randomly chosen person will be unemployed. Here, we take a dynamic approach and estimate the underlying movements of workers into and out of unemployment. These are typically referred to as the inflow rate $\left(s_{t}\right)$, which is the pace at which workers move into unemployment and the outflow rate $\left(f_{t}\right)$, the pace at which workers move out of unemployment.

During recessions, generally, we see more people losing jobs and becoming unemployed, hence we expect the inflow rate to increase. At the same time, it is harder for people to find jobs, hence we expect the outflow rates to decrease. Yet, there is a disagreement in the literature as to which is the main driver of the

\footnotetext{
${ }^{2}$ http://www.nytimes.com/2010/08/07/opinion/07phelps.html

${ }^{3}$ http://www.federalreserve.gov/monetarypolicy/files/fomcminutes20110126.pdf
} 
unemployment rate. Earlier literature found flows into unemployment to be the main driver of unemployment hence "The Ins Win" title of the seminal paper by Darby et al. (1986). Later work claimed the opposite with Robert Hall (e.g. Hall (2005a), Hall (2005b)) and Robert Shimer (e.g. Shimer (2005b), Shimer (2007)) being, perhaps, the strongest voices arguing that "outs" of unemployment explain much of unemployment dynamics. Finally, a recent strand of literature finds that "everyone's a winner"-i.e. both ins and outs are important for a complete understanding of cyclical unemployment (Elsby et al. (2009)). In this paper, we revisit this issue during the most recent downturn by extending the focus to industries.

We use Shimer's methodology for computing flows into and out of unemployment. We assume that during period $t$ the job finding (outflow) rate and job separation (inflow) rate are governed by a Poisson process with arrival rate $f_{t}$ and $s_{t}$, respectively. That is unemployed workers find a job according to $f_{t} \equiv-\log \left(1-F_{t}\right) \geq 0$ and employed workers lose a job according to $s_{t} \equiv-\log \left(1-S_{t}\right) \geq 0 . F_{t}$ and $S_{t}$ are finding and separation probabilities. $^{4}$

We follow the model outlined in Shimer (2007) in which unemployment and short-term unemployment increase and fall according to

$$
\begin{gathered}
\dot{u}_{t+\tau}=e_{t+\tau} s_{t}-u_{t+\tau} f_{t} \\
\dot{u}_{t}^{s}(\tau)=e_{t+\tau} s_{t}-u_{t}^{s}(\tau) f_{t}
\end{gathered}
$$

where $e_{t+\tau}$ is the number of employed workers at time $t+\tau, u_{t+\tau}$ is the number of unemployed workers, and $u_{t}^{s}(\tau)$ is short-term unemployment, i.e. workers who are unemployed at time $t+\tau$, but were employed at some time before $t^{\prime} \in[t, t+\tau]$. Once the equation is solved and a number of simplifying assumption imposed, the number of unemployed workers at time $t+1$ is equal to the number of workers at time $t$ who do not find a job (fraction $1-F_{t}=\exp ^{-f_{t}}$ ) plus the number of short-term unemployed workers $u_{t+1}^{s}$, those who are unemployed at $t+1$, but held a job at some point during time $t$.

$$
u_{t+1}=\left(1-F_{t}\right) u_{t}+u_{t+1}^{s}
$$

Thus the monthly job finding probability is equal to

$$
F_{t}=1-\left[\frac{u_{t+1}-u_{t+1}^{s}}{u_{t}}\right]
$$

\footnotetext{
${ }^{4}$ Probabilities summarize the concentration of spells at each instant along the time axis, while rates summarize the same concentration at each point of time, but conditional on survival in that state up to that instant.
} 
and the outflow hazard is then

$$
f_{t} \equiv-\log \left(1-F_{t}\right)=-\log \left[\frac{u_{t+1}-u_{t+1}^{s}}{u_{t}}\right]
$$

Finding the inflow hazard is more complicated as some workers that flow into the unemployment pool exit unemployment before the next period, hence they are not counted and as a result the measured stock of short-term unemployed is in fact underestimated. One can solve equation (1) to obtain an implicit expression for the separation probability

$$
u_{t+1}=\frac{\left(1-\exp ^{-f_{t}-s_{t}}\right) s_{t}}{f_{t}+s_{t}} l_{t}+\exp ^{-f_{t}-s_{t}} u_{t}
$$

where $l_{t} \equiv u_{t}+e_{t}$ is the size of the labor force during period $t$.

This continuous time formulation allows to avoid the time aggregation bias that occurs in a discrete time model in which the information on workers that lose and find a new job within the same period is omitted. For more details, see Shimer (2007). ${ }^{5}$

Having obtained industry-specific series for short-term unemployed, unemployed and the labor force, we are able to compute industry-specific job finding and separation probabilities. That is for each industry we use the industry-specific version of equations 4 and 6 :

$$
F_{i, t}=1-\left[\frac{u_{i, t+1}-u_{i, t+1}^{s}}{u_{i, t}}\right]
$$

and

$$
u_{i, t+1}=\frac{\left(1-\exp ^{-f_{i, t}-s_{i, t}}\right) s_{i, t}}{f_{i, t}+s_{i, t}} l_{i, t}+\exp ^{-f_{i, t}-s_{i, t}} u_{i, t}
$$

where i stands for industry or occupation $i$.

\subsection{Contributions of Flows to Aggregate Unemployment Rate Changes}

In addition to computing flows into and out of unemployment, we want to understand what is the contribution of these flows to increases in the unemployment rate during recessions and declines in unemployment rate during recoveries. Studies have shown that actual unemployment rate $\left(\tilde{u}_{t}\right)$ dynamics are closely approximated

\footnotetext{
${ }^{5} \mathrm{An}$ alternative approach to correct the CPS data for the time aggregation bias would be to impute discrete weekly hazard rates. Elsby et al. (2009) show that both types of correction yield broadly similar results.
} 
by the steady state unemployment rate $\left(u_{t}^{*}\right)(\text { Shimer }(2005 \mathrm{a}))^{6}$

$$
\tilde{u}_{t} \equiv \frac{u_{t}}{l_{t}} \approx u_{t}^{*}=\frac{s_{t}}{s_{t}+f_{t}}
$$

We take advantage of this and compute a series of hypothetical unemployment rates that allow us to obtain the contributions. First, we identify the dates for the pre-recessionary troughs and recessionary peaks in the steady-state unemployment rate series. Let $t_{1}$ be the date of pre-recessionary trough in the unemployment rate and $t_{2}$ be the date of the recessionary peak. The recessionary change in the unemployment rate is then approximated by $u_{t 2}^{*}-u_{t 1}^{*}$. To get to the contribution of job finding probability changes to the recessionary increase in the unemployment rate, we fix job separation rate at its value at the data when the pre-recessionary trough in the unemployment rate was achieved (i.e. set $s=s_{t_{1}}$ ) and compute a hypothetical unemployment rate for each period $t \in\left[t_{1}, t_{2}\right]$ :

$$
u_{t}^{H 1}=\frac{s_{t_{1}}}{s_{t_{1}}+f_{t}}
$$

Similarly, to compute the contribution of job separation probability changes to the recessionary increase in the unemployment rate, we fix the job finding rate at the date when the pre-recessionary trough in the unemployment rate is achieved (i.e. set $f=f_{t_{1}}$ ) and compute a hypothetical unemployment rate for each period $t \in\left[t_{1}, t_{2}\right]$ :

$$
u_{t}^{H 2}=\frac{s_{t}}{s_{t}+f_{t_{1}}}
$$

Figure 6 shows $u^{*}, u^{H 1}$ and $u^{H 2}$ series for the recessions in our sample. We compute the contribution of job finding probability changes to the recessionary aggregate unemployment increase as:

$$
\text { fcontr }=u_{t 2}^{H 1}-u_{t 1}^{H 1}
$$

We find the contribution of job separation probability changes to the recessionary aggregate unemployment rate increase as:

$$
\text { scontr }=u_{t 2}^{H 2}-u_{t 1}^{H 2}
$$

We are interested in computing the contributions of industry-specific job finding and job separation probability to the recessionary unemployment rate increase for that industry and also for the aggregate unemployment rate increase. This requires to follow the same steps as for the aggregate unemployment rate.

\footnotetext{
${ }^{6}$ This holds quite well in our sample. The correlation between aggregate steady state and aggregate actual unemployment rates over the sample period is 0.98 .
} 
First, the necessary assumption that steady state unemployment rate is a good approximation for the actual unemployment rate also holds reasonably well for the industry-specific series. For the industries of focus, the correlation between actual and steady state quarterly unemployment rate series is above 0.92 for all series. Thus, we assume that the following holds for each industry $i$ :

$$
\tilde{u}_{i, t} \equiv \frac{u_{i, t}}{l_{i, t}} \approx u_{i, t}^{*}=\frac{s_{i, t}}{s_{i, t}+f_{i, t}}
$$

We then compute the two hypothetical unemployment rates for industry $i$ :

$$
u_{i, t}^{H 1}=\frac{s_{i, t_{1}}}{s_{i, t_{1}}+f_{i, t}}
$$

and

$$
u_{i, t}^{H 2}=\frac{s_{i, t}}{s_{i, t}+f_{i, t_{1}}} .
$$

The contributions of industry-specific job finding and separation probabilities to the group-specific unemployment rate increase are simply computed as:

$$
\text { fcontr }_{i}=u_{i, t 2}^{H 1}-u_{i, t 1}^{H 1}
$$

and

$$
\text { scontr }_{i}=u_{i, t 2}^{H 2}-u_{i, t 1}^{H 2},
$$

where $t_{1}$ is the date of the pre-recessionary trough in the aggregate unemployment rate. Finally, we compute the contribution of industry-specific job finding and contribution probability to the aggregate unemployment increase rate as:

$$
\text { agfcontr }_{i}=\frac{\text { fcontr }_{i}}{\text { scontr }_{i}+f \text { contr }_{i}}\left(w_{i, t_{2}} * \tilde{u_{i, t_{2}}}-w_{i, t_{1}} * \tilde{u_{i, t_{1}}}\right)
$$

and

$$
\text { agscontr }_{i}=\frac{\text { scontr }_{i}}{\text { scontr }_{i}+f \text { contr }_{i}}\left(w_{i, t_{2}} * \tilde{u_{i, t_{2}}}-w_{i, t_{1}} * \tilde{u_{i, t_{1}}}\right)
$$

where $w_{i, t}$ is industry i's share in the labor force at time $t$.

We then repeat the exercise for post-recessionary unemployment rate declines. In that case, $t_{1}$ becomes the date of the recessionary peak in the aggregate unemployment rate and $t_{2}$ is the period 9 quarters after the beginning of the recession (the most recent data we have available). Alternatively, one could make $t_{2}$ the date of unemployment rate trough after the recession, but at the time we are conducting this analysis, 
the trough in the aggregate unemployment rate has yet to be achieved.

\section{Data}

We use current, publicly available data from the Current Population Survey (CPS). The CPS is a monthly survey of households conducted by the U.S. Bureau of Census for the Bureau of Labor Statistics. It provides data on the labor force, employment, unemployment, persons not in the labor force, hours of work, earnings, and other demographic and labor force characteristics. Three series are necessary to compute unemployment inflow and outflow rates by industry: the number of unemployed, the unemployment rate and the number of short-term unemployed (those unemployed for less than 5 weeks). These series are available for the broadest industry classification from BLS, but only from 2000. In order to gain insight into whether the current changes in the US labor market are due to a cyclical slowdown or structural realignment and to compare those changes with past downturns, we need data that go back beyond 2000. To obtain such data, we go to monthly CPS microdata and construct the desired series. Our task is complicated by the fact that there are several different "periods" of industry data because of changes in industry classification of the CPS: 19761982, 1983-2002 and 2003-2011. In order to convert the 1976-1982 and the 1983-2002 period data to the 2002 classification we go through industry sub-categories and create industry definitions that are consistent across time.Next, an industry conversion table provided by the $\mathrm{BLS}^{7}$ is used to reweigh the old industry categories into the new ones (Appendix Table A1). These factors are based on three-year average survey microdata (2000-2002) that were coded to both the old and new classification systems. ${ }^{8}$ This exercise allows us to extend our data back to 1976 in a consistent manner. We have 9 industries: agriculture, mining, construction, manufacturing, transportation and public utilities, wholesale and retail trade, FIRE (finance, insurance and real estate), all services and public administration. ${ }^{9}$ In order to check whether the generated results are reasonable we compare the generated series with the aggregates that are available from BLS from 2000 onward. Figure A1 provides a comparison of the generated series and the BLS published aggregate series for the labor force. The figure also provides the correlation coefficient between the BLS and the created series. We see that (aside from agriculture) the created series' match well the BLS published series' with a correlation above 0.97 . Given that they track each other reasonably well, one can have confidence the proposed methodology is correct.

\footnotetext{
${ }^{7}$ http://www.bls.gov/cps/cpsoccind.htm

${ }^{8}$ We use the industry names similar to the 1990 categories, but with industries being reclassified. For example, services include information, professional and business services, education and health services, leisure and hospitality and other services. When using these conversion factors we should keep in mind that the accuracy of the constructed series is affected by the changing employment distribution. The conversion factors are based on the distribution of employment that existed in $2000-02$. That distribution may have changed over time, and, therefore, the constructed series may not reflect the actual employment distribution during earlier time periods.

${ }^{9} \mathrm{~A}$ finer disaggregation is not feasible as mapping becomes very difficult and few observations are present.
} 


\subsection{Descriptive statistics}

Next, we take a look at some descriptive statistics in order to gain some background information regarding the situation in the chosen industries. In Table 1 in the top panel we compare the average industry share of the labor force. We examine these trends over time to better understand the role the industries play in the economy. For most industries, the share has been stable over time. Changes have been observed in the two largest sectors in terms of employment: manufacturing and services, with the share of labor diminishing in the former and increasing in the latter. In the second panel, we compare the average industry unemployment rate (1976-2010) with the one in this last recession, which indicates that construction, finance and manufacturing have been hit particularly severely, followed by wholesale and retail, transportation, and services. In the public administration sector the unemployment rate has (so far) been less than the average rate. Finally, in the third panel we look at the volatility of unemployment by looking at the standard deviation for each group. In the industry classification, we see that mining and construction are traditionally the most volatile sectors. In the last recession, all sectors have been more volatile compared to their historical average, except for public administration. In addition, construction, FIRE and manufacturing exhibit almost double their volatility $(1.76,1.88$ and 1.88 , respectively) indicating that this is a particularly unusual recession for these sectors by historical standards.

\section{Results}

As is well documented, the U.S. economy entered a severe recession in December 2007. Aggregate unemployment rate peaked at 10.1 percent in October 2009 (Figure 1) and, although the recession "officially" ended in June $2009^{10}$, unemployment remains stubbornly high (above 8 percent) as we write. The aggregate picture masks differences across various socio demographic sub-groups and sectors of the economy. During the Great Recession, researchers paid attention to experiences of different socio-demographic groups, identifying the young, minorities and men as the groups experiencing the greatest impact (e.g. Elsby et al. (2010)). Others also hypothesized that some of the variation in experiences for different socio-demographic groups comes from industry and occupation segregation (Sierminska and Takhtamanova (2011)). In this paper we focus on the situation within and across industries in terms of unemployment and industry job market flows.

In what follows we first examine the unemployment situation across industries and compare the contribution of each of them to the aggregate unemployment rate changes. Then, we look at industry specific flows into and out of unemployment. In the last section we analyze differences across industries by examining diffusion indices.

\footnotetext{
${ }^{10}$ According to the National Bureau of Economic Analysis
} 


\subsection{Industry-specific unemployment rates.}

To begin the investigation into which sectors of the economy have been affected the most, we start off by presenting industry-specific unemployment rates in Figure 2. The figure allows for comparisons of each industry's experience to average. Gray solid lines show the aggregate unemployment rate and the gray horizontal line shows the average aggregate unemployment rate over the sample period. The dashed lines are unemployment rates and sample averages (horizontal line) for each industry.

Public administration seems to have been one sector most sheltered during this recession. For all other industries unemployment rate during the Great Recession exceeded both the aggregate and industry-specific long-run average. In contrast, the unemployment rate for public administration barely exceeded its industryspecific long-term average and remains well below that aggregate long-term average unemployment rate. By this measure, the twin recession of the early 1980s is a much more severe recession for this sector.

In terms of the industries most affected by the downturn, manufacturing, construction and FIRE (finance, insurance and real estate) stand out. The latter two have received particular attention during the downturn. Construction is a more cyclically sensitive sector of the two, displaying higher than average unemployment rate and more volatility. Unemployment rate in construction jumped to 20 percent during the recession and is well above the average unemployment rate for all industries and its own long-term average rate. For FIRE, unemployment rate reached a peak of slightly above 7 percent during the recession, which is well above the long-term average unemployment rate for this industry and is close to the long-term average unemployment rates for all industries. This occurred for the first time since the 1970s.

This is confirmed and shown in a different way in Figure 3. Here we see the evolution of the unemployment rate since the peak of the business cycle. According to this figure industries have been affected with a varying delay and the reduction in unemployment is also occurring at different times. The highest rate of increase in the unemployment rate has occurred for manufacturing, then construction, followed by transportation and wholesale and retail. A slower pace of increase has been taking place in FIRE and there has been a much more delayed increase in public administration. Compared to other recessions this has been the most severe recession in terms of the speed of unemployment growth in construction, FIRE, manufacturing, services and transportation. For public administration it does not seem like unemployment has reached its peak. The recovery in most industries, but particularly in public administration and services seems to be very slow.

Figure 4 shows us the aggregate increase and decline during recessions and gives us one way to compare the severity across recessions for each industry. Our findings, to some extent, confirm the results from the previous figure. Apart from the fact that construction and manufacturing have been the most severely hit in this recession (by this measure) we find that this recession has been the most severe based on the past 
four for all industries except services. What we also see is that construction and manufacturing (although to a smaller extent than in previous recessions) are bouncing back, but public administration, services, transportation and wholesale and retail trade are not. Based on the growing labor share of services alone in the labor force this is a severe problem in the labor market. In the following section, we look at this in more detail, by examining the flows into and out of the labor market.

Industries contribution to the unemployment rate. Apart from examining how severely the recession has hit different sectors we want to see, the extent to which each industry has contributed to the change in the aggregate unemployment rate. The contributions are shown separately in Table 2 for the aggregate unemployment rate increase from the pre-recession trough (March 2007) to the recession peak (October 2009) in the top panel and then in the bottom panel for the aggregate unemployment rate decline from the recession peak to the latest observation available (December 2011).

In both panels in the first row we show the industry's average share in the labor force during each recession episode in our sample. The second row shows each industry's contribution to the aggregate unemployment rate increase (or decline) during the recession episode computed as following:

$$
\text { urcontr }_{i}=\frac{w_{i, t_{2}} * u_{i, t_{2}}-w_{i, t_{1}} * u_{i, t_{1}}}{\sum\left(w_{i, t_{2}} * u_{i, t_{2}}-w_{i, t_{1}} * u_{i, t_{1}}\right)}
$$

where $w_{i, t}$ is industry $i$ 's share in the labor force at time $t, u_{i, t}$ is industry $i$ 's unemployment rate at time $t, t_{1}$ and $t_{2}$ are either dates for the aggregate unemployment rate pre-recession trough and recession peak respectively (if industry's contribution to the recessionary increase in the aggregate unemployment rate is being calculated) or the dates for recession peak and the period 9 quarters since then (if the industry's contribution to the decline in the aggregate unemployment rate us being calculated).

During the last recession, for example, almost 40 percent of the aggregate unemployment rate increase came from services. This is not surprising, given that services industry constituted almost half of the labor force during the recession (as shown in the first row of the figure). Thus, services' contribution to the aggregate unemployment rate increase was slightly below the sector's share in the labor force. The services' contribution is followed by manufacturing and construction.

The third row shows the ratio of each industry's contribution to the aggregate unemployment rate increase to the industry's share in the labor force. For services, this ratio was $0.8 .{ }^{11}$ Thus construction and manufacturing have contributed the most to the unemployment rate increase in relation to their labor force share. In this recession public administration stands out as the most "sheltered" sector, followed by FIRE. This measure of industry's "burden" does not imply, however, that the burden borne by construction and

\footnotetext{
${ }^{11} \mathrm{~A}$ ratio of less than one indicates the industry's contribution was than it's labor force share.
} 
manufacturing is unprecedented - for manufacturing, the twin recessions of the 1980s were as severe; for construction, the recession of the early 1990s appears to be as severe as the most recent one as well. Thus, in terms of the increase of the unemployment rate we do not find any spectacular differences compared to past recessions.

In the bottom panel of Table 2 we see the exact same figures but for the industry's contribution to the aggregate unemployment rate decline during the recovery. In the most recent recovery, construction and manufacturing appear to have "bounced back" rather well and are the main contributors to the modest decline in the aggregate unemployment rate observed during the recovery as of the end of 2011. In addition their contribution to the decline exceeds several times their share in the labor force. On the other hand, the recovery in FIRE is rather stagnant and public administration is actually on the decline - this sector is providing upwards pressure on the aggregate unemployment rate during the recovery. The biggest factor though seems to be services. The recovery here has yet to take place and given that it's share is almost half of the labor force this is what is dragging the fall in unemployment.

\section{$4.2 \quad$ Job Flows}

Aggregate job flows and their contributions to the aggregate unemployment rate changes Was it the job loss or the difficulty in finding a job that drove the unemployment rate to its impressive heights? That is, what were the roles of job separation and finding rate in the aggregate unemployment rate increase? In the first instance we focus on the aggregate job finding and separation probabilities to gain insight into the aggregate unemployment rate changes. Figure 5 plots both at a quarterly frequency. The average job finding probability during the period (January 1976 - December 2011) is 40.6 percentage points, while the average job separation probability is rather low at 3.4 percentage points. The job finding probability is more volatile.

Shimer (2007) points out a secular decline in job separation probability since the early 1980s. During the Great Recession, however, job separation probability increased noticeably from 2.5 percentage points at the pre-recession trough in the first quarter of 2007 to the 3.2 percentage points at the recessionary peak (reached in the fourth quarter of 2008). It does not appear, though, that this recently observed spike in job separation probability breaks the trend - the peak observed is still below those observed in the past recession.

It is the decline in job finding probability - from the peak of about 45 percentage points in the third quarter of 2006 to the unprecedented low of 20 percentage points in the first quarter of 2010 - that truly stands out. From Figure 5 we see the decline in job finding probability began slightly before the rise in job separation probability (the peak of job finding probability falls on the third quarter of 2006, whereas 
the trough of job separation probability occurs in the first quarter of 2007). To understand what is driving increases in the unemployment rate, it is useful to look at the relative contributions of falling job finding probability and rising job separation probability and examine how those contributions change over time.

Figure 7 shows the relative contributions of the two rates to the aggregate unemployment rate increase during the recession and aggregate unemployment rate decline during the recovery (computed as discussed in the methodology section). For all recessions shown, the job finding rate explains the majority of the recessionary peak-to-trough increases in the aggregate unemployment rate, and its role becomes increasingly important as the recession progresses. However, separation from employment also plays a significant role in unemployment rate fluctuations, especially early in the recession and particularly during the two most severe recessions in the sample (the twin recessions of the 1980s and the recession of 2007).

Job finding probability plays a dominant role in the unemployment rate decline during the recovery for the first three recessions in our sample (as is shown in the bottom panel of Figure 7). However, our results suggest that this is not the case in the most recent recovery. Our results imply that in the most recent recovery, job finding probability did not pick up sufficiently to drive down the unemployment rate. Thus, the modest decline in the unemployment rate observed to date has been driven by declines in job separation probability.

\section{Job flows by industry and their contributions to the aggregate unemployment rate changes}

Next, we focus on industry-specific flows. Public administration has the lowest average job separation probability for the sample (1 percent) and construction has the highest (6 percent). In terms of job finding probability, the highest sample averages are observed for agriculture, services and wholesale and retail trade (44 percent for construction and 42 percent for both wholesale and retail trade and services), whereas public administration has the lowest average job finding probability (35 percent).

The job finding and separation probabilities for all industries but mining are shown in figures 8 and 9 . The figures show the dynamics of job finding and separation probabilities respectively from the peak of the business cycle. Figure 8 shows that the decline in job finding probability during the most recent downturn is considerably more pronounced than it was for the previous recessions for all the industries shown. As with the aggregate job finding probability series, during the most recent downturn, job finding probability for all industries reached its lowest point in the history of the series. Some industries were impacted sooner than others. Construction and manufacturing are the industries that first experienced a decline in job finding probability ( $3^{\text {rd }}$ quarter of 2006), followed by wholesale and retail trade ( $1^{\text {st }}$ quarter of 2007), transportation and utilities and services ( $3^{\text {rd }}$ quarter of 2007) and then FIRE and public administration ( $4^{\text {th }}$ quarter of 2007). Although it was impacted later than other industries FIRE stands out with job finding probability 
dropping below the both aggregate and industry-specific long-run average rates. Job finding probability appears to have began recovering for construction, manufacturing and wholesale and retail trade industries, but it is stagnant for the other sectors. Irrespective of showing improvements, for all the industries, job finding probability remains at remarkably low levels.

Turning to job separation probability (figure 9), the peak of job separation probability observed during the most recent downturn is not without precedent - job losses in previous recessions caused larger job separation probability spikes. Just like with the job finding probabilities, some industries were impacted sooner than others. Construction, FIRE, manufacturing and public administration exhibit noticeable increases in job separation probability, with construction and manufacturing being "hit" first, followed by FIRE and then public administration.

The contributions of job finding and job separation probabilities to the aggregate unemployment rate changes during recession and recovery are summarized in Table 3. The top panel of the table shows each industry's contribution to the aggregate unemployment rate increase (pre-recession trough to recessionary peak) for each of the four recessions. For instance, the table shows that the decline in job finding rate in construction contributed 0.58 percentage points to the aggregate unemployment rate increase during the most recent downturn - the largest contribution of job finding in construction to the a recessionary unemployment rate increase during our sample period. The increase in job separation rate in construction contributed 0.27 percentage points to the aggregate unemployment rate decrease - again, the largest contribution of job separation rate in this industry to the recessionary aggregate unemployment rate increase. The decline in job finding probability in services was by far the largest contribution to the aggregate unemployment rate increase - it was as high as 1.86 percent (which is not surprising, given that services have such a high share in the labor force). Job finding in manufacturing was the second highest contributor the the aggregate unemployment rate increase (0.63 percentage points), with wholesale and retail trade following close behind (0.6 percentage point). In terms of job separation, the largest contributor was construction - the increase in job separation in this sector contributed 0.27 percentage points to the aggregate unemployment rate increase, followed by manufacturing ( 0.24 percentage points).

During the recovery (see the bottom panel of Table 3), our results imply that declines in job separation probability in construction and manufacturing played the largest role in the aggregate unemployment rate declined observed after the Great Recession. Improvements in job finding probability in these two sectors also provided sizeable contributions to the aggregate unemployment rate decline. Meanwhile, services, which typically would be aiding the recovery, have not helped the aggregate unemployment rate decline in recent months. Contraction in public administration employment actually put upward pressure on the aggregate unemployment rate during the most recent recovery (in contrast to the past episodes). It is the low job 
finding probability in public administration, in particular that is at play.

\subsection{Diffusion indices}

With the industry- and occupation-specific job finding and separation probabilities in hand, we look at the dispersion of job finding probability to assess the degree of differences across industries. Large differences would signal presence of structural changes. As discussed in the introduction, structural and cyclical changes in the unemployment rate call for different policy response.

The original Lilien (1982) dispersion measure served as a way to quantify the degree of sectoral reallocation in an economy at any given time. His original measure referred to employment growth. Here, we examine the dispersion of flows out of unemployment (job finding probability) as a weighted average of squared deviations of industry (or occupation) flows from the aggregate. Lilien's measure is given by

$$
\sigma_{L t} \equiv \sqrt{\left[\sum_{i} w_{i t}\left(g_{i t}-g_{t}\right)^{2}\right]},
$$

where $w_{i t}$ is each industry's share in the labor force, $g_{i t}$ is each industry's job finding rate and $g_{t}$ is the aggregate job finding rate.

It is well known that Lilien's dispersion measure may be over-stating the degree of structural changes in the economy Abraham and Katz (1986) and other measures have been developed (see, for instance Rissman (2009)). However, in our case, an alternative measure is not necessary (see the discussion that follows).

Examining the differences in industry-specific job finding probabilities is useful to assess the degree of sectoral reallocation that takes place in the economy. If we see large differences across industries we can suspect that perhaps sectoral reallocation is taking place. We calculate the dispersion index of job finding probabilities across industries using Lilien's measure given in equation (22) and plot it in Figure 11. We see that this measure of dispersion rose during the recessions to levels comparable to those observed during the twin recessions of the 1980s, as job finding probability in some industries was falling sooner than in others. However, the dispersion index fell more recently, as job finding probability fell across all industries.

There are a couple of useful benchmarks we thought of when trying to assess the degree of job finding dispersion across industries. One is to compare the dispersion attained during this recession to that achieved during the twin recession of the 1980s. The twin recession of the 1980s is an important benchmark, as that recession is not generally thought of as the one associated with large structural changes (see Valletta and Kuang (2010)). As Figure 11 shows, the degree of dispersion attained during this recession is not materially above that attained during the early 1980s. Another benchmark that can be used is the maximum degree 
of dispersion during the 2000-2007 period, which is the period associated with stable NAIRU. ${ }^{12}$ Again, the level of dispersion attained during the recession of 2007 and the recovery is below that benchmark as well. Thus, based on this criteria, we do not have evidence in support of large structural changes under way in the U.S. economy.

As previously mentioned, the presented Lilien diffusion index is known for over-stating the degree of structural change. Given our conclusion, however, this does not appear to be an issue in our case as we do not find evidence to support the structural change hypothesis. Using a less biased estimate would likely only strengthen our conclusion.

\section{$5 \quad$ Summary and Discussion}

In this paper, based on industry specific data we find that during recessions (and recoveries) industries were affected with a different intensity. Services, manufacturing and construction contributed the most to the increase in the aggregate unemployment rate. Construction, though, can be considered as much harder hit, as its contribution to the unemployment rate by far exceeds more than its labor force share (the opposite is true for services - its contribution to the unemployment rate increase is below its labor share). Another relatively large sector (labor force share exceeds 10 percent) that suffered disproportionately more by this measure is manufacturing. FIRE, a sector of interest during the recent downturn, also experienced an increase in unemployment, but one that is below its share in the labor force. Thus, it could be considered as unaffected, relatively speaking. At the same time, construction and manufacturing, unlike financial services, rebounded relatively well during the recovery, thus contributing more than their labor force share to the aggregate unemployment rate decline during the recovery. Services, on the other hand, which constitute about half of the labor force have not rebounded and are still keeping the unemployment rate high by not contributing to its decline. The severity of the situation is confirmed to some extent when data on the length of unemployment is considered. Findings from 2010 indicate that across industries, jobless individuals from manufacturing, information, and financial activities are the most likely to be long-term unemployed (Autor (2010)).

When job flows are considered we find that industries are affected at different times. FIRE is the last industry that saw the job separation probability hit its minimum point in this recession. At the same time its the last one to see its job finding probability hit the lowest point.

Although, there is some variation in the job finding probability performance across industries, we do not find evidence from the labor market data we analyzed in support of large structural changes in the U.S.

\footnotetext{
${ }^{12}$ Periods of stable NAIRU can be classified as periods without large structural changes in the labor market. The CBO estimate of NAIRU for this entire period is 5 percent.
} 
labor market. The diffusion index we considered is not unusually high in comparison to chosen benchmarks. Further analysis could examine evidence by occupation to check the robustness of our findings. 


\section{References}

Abraham, K. G. and Katz, L. F. (1986). Cyclical unemployment: Sectoral shifts or aggregate disturbances? Journal of Political Economy, 94:507-522.

Autor, D. H. (2010). U.S. Labor Market Challenges over the Longer Term.

Autor, D. H. (2011). Impending labor market challenges: Males between the blades of the marshallian scissors.

Darby, M. R., Haltiwanger, J. C., and Plant, M. W. (1986). The ins and outs of unemployment: The ins win. NBER Working Papers 1997, National Bureau of Economic Research, Inc.

Elsby, M., Hobijn, B., and Sahin, A. (2010). The Labor Market in the Great Recession. Brookings Papers on Economic Activity, forthcoming.

Elsby, M. W. L., Michaels, R., and Solon, G. (2009). The Ins and Outs of Cyclical Unemployment. American Economic Journal: Macroeconomics, 1(1):84-110.

Hall, R. E. (2005a). Employment Efficiency and Sticky Wages: Evidence from Flows in the Labor Market. The Review of Economics and Statistics, 87(3):397-407.

Hall, R. E. (2005b). Job Loss, Job Finding, and Unemployment in the U.S. Economy Over the Past Fifty Years. NBER Working Papers 11678, National Bureau of Economic Research, Inc.

Rissman, E. (2009). Employment growth: Cyclical movements or structural change? Federal Reserve Bank of Chicago Economic Perspectives, 2009/Q4.

Shimer, R. (2005a). The cyclical behavior of equilibrium unemployment and vacancies. American Economic Review, 95:25-49.

Shimer, R. (2005b). The cyclicality of hires, separations, and job-to-job transitions. Technical Report Jul.

Shimer, R. (2007). Reassessing the ins and outs of unemployment. NBER Working Paper 13421, NBER.

Sierminska, E. and Takhtamanova, Y. (2011). Job flows, demographics and the great recession. Research in Labor Economics, 32:115-154.

Valletta, R. and Kuang, K. (2010). Is structural unemployment on the rise? FRBSF Economic Letter, 34. 


\section{$6 \quad$ Tables and Figures}

Figure 1: The aggregate and industry unemployment rate during 1976-2011.

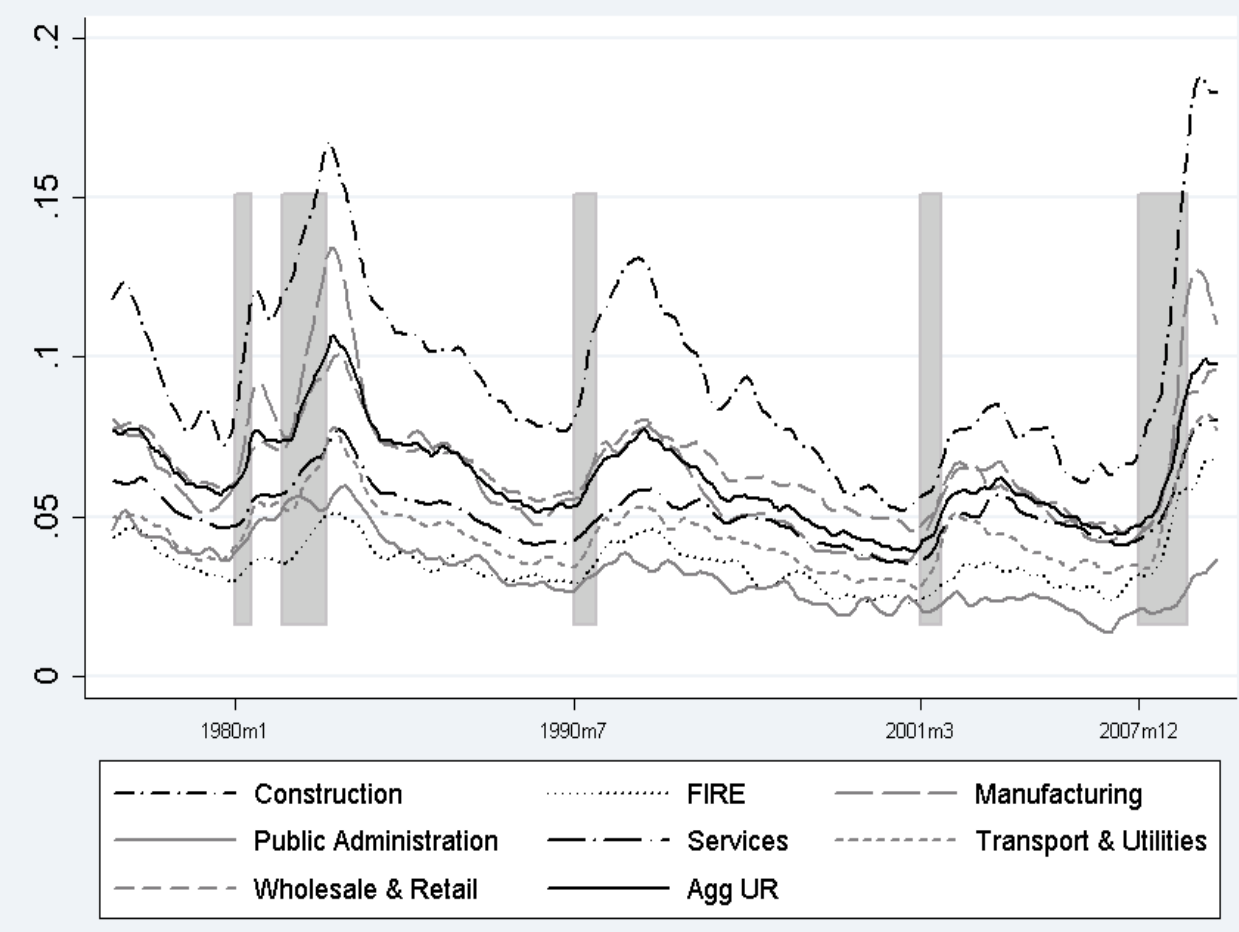

Source: Bureau of Labor Statistics, Current Population Survey. 


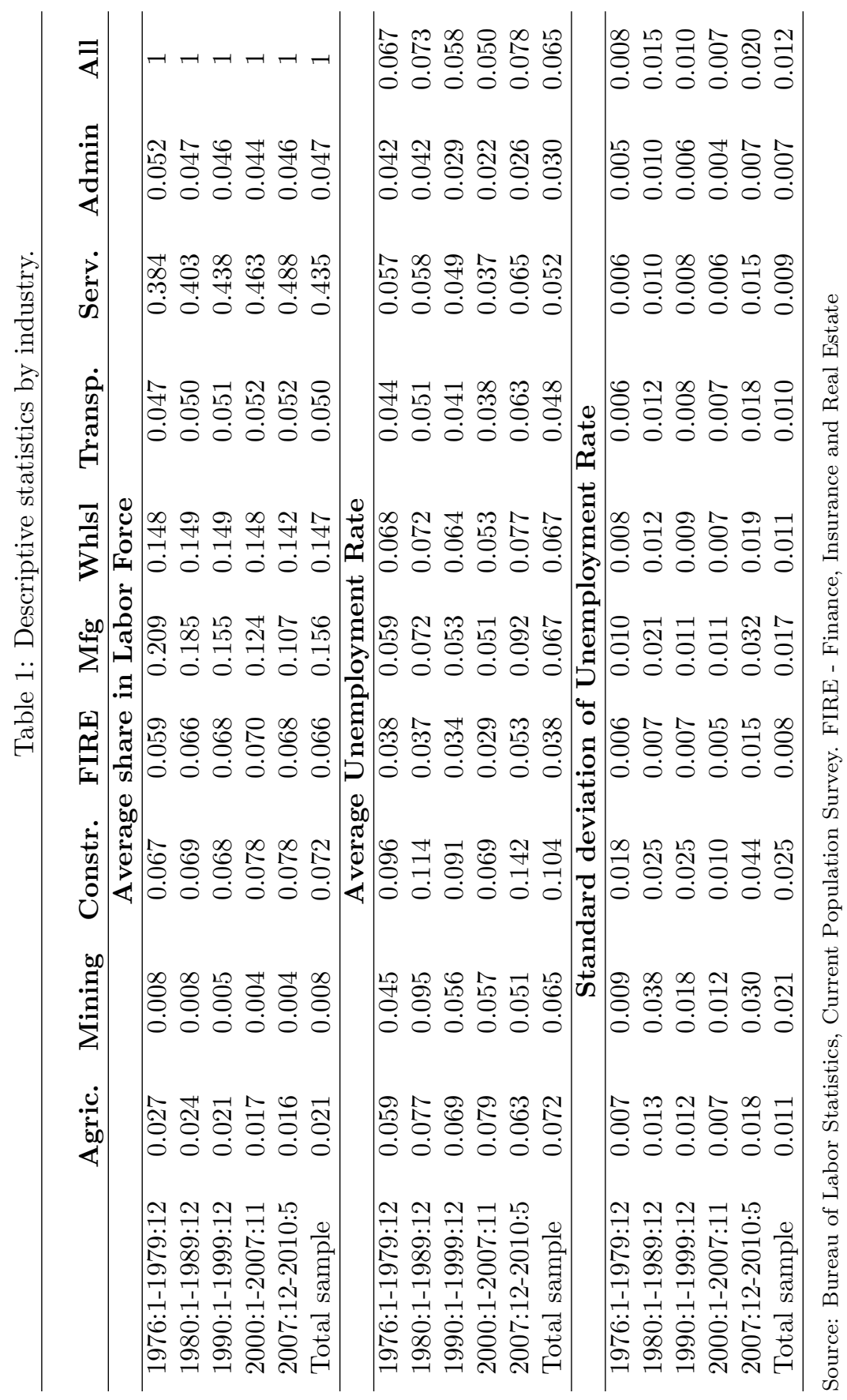


Figure 2: Industry and aggregate unemployment rate during 1976-2010.
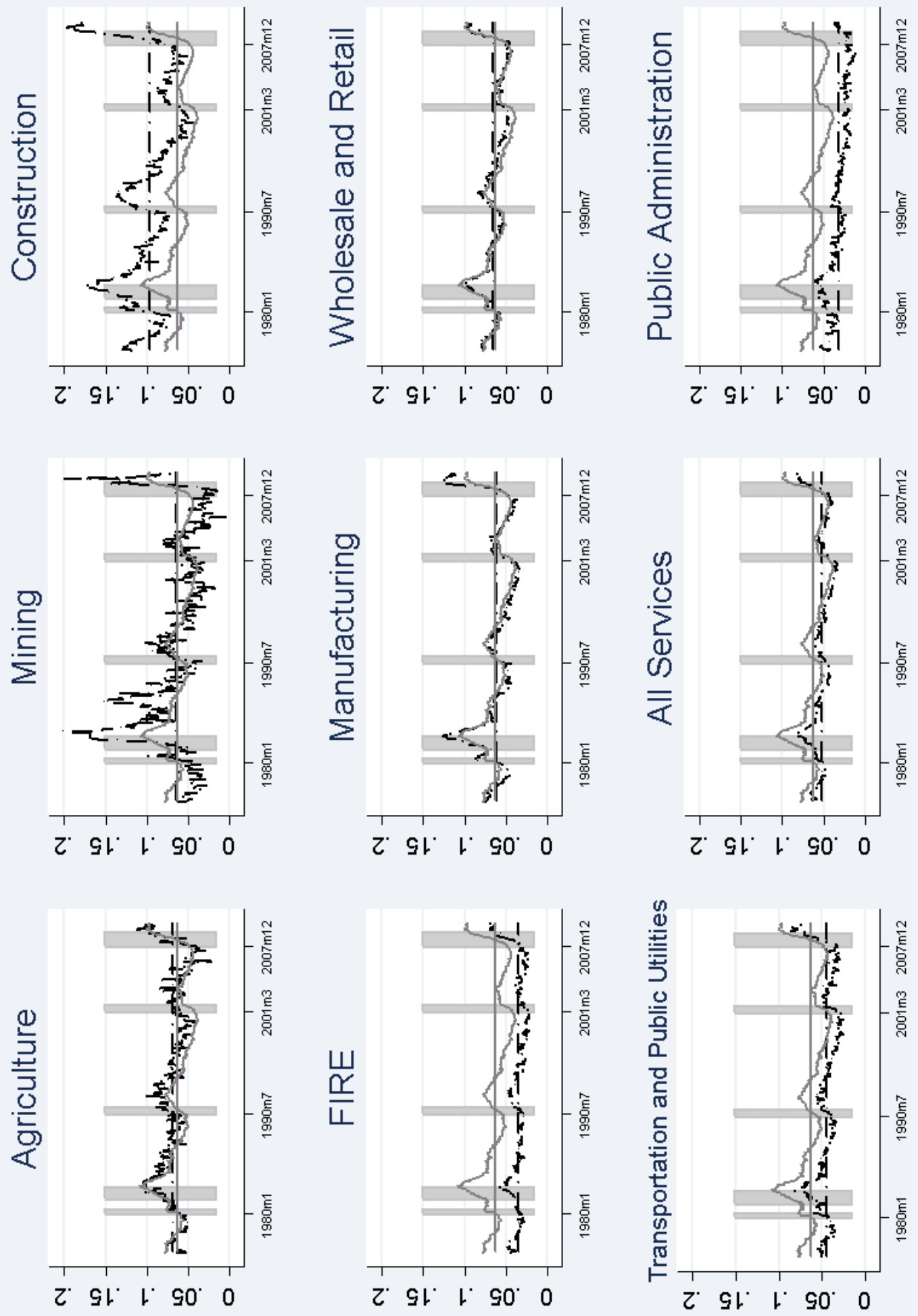

Source: Bureau of Labor Statistics, Current Population Survey.

Note: Sold lines represent the aggregate unemployment rate and the average unemployment rate. Dashed lines represent the industry unemployment rate and average unemployment rate during the period. 
Figure 3: The aggregate and industry unemployment rate during 1976-2011 (months since peak of business cycle).
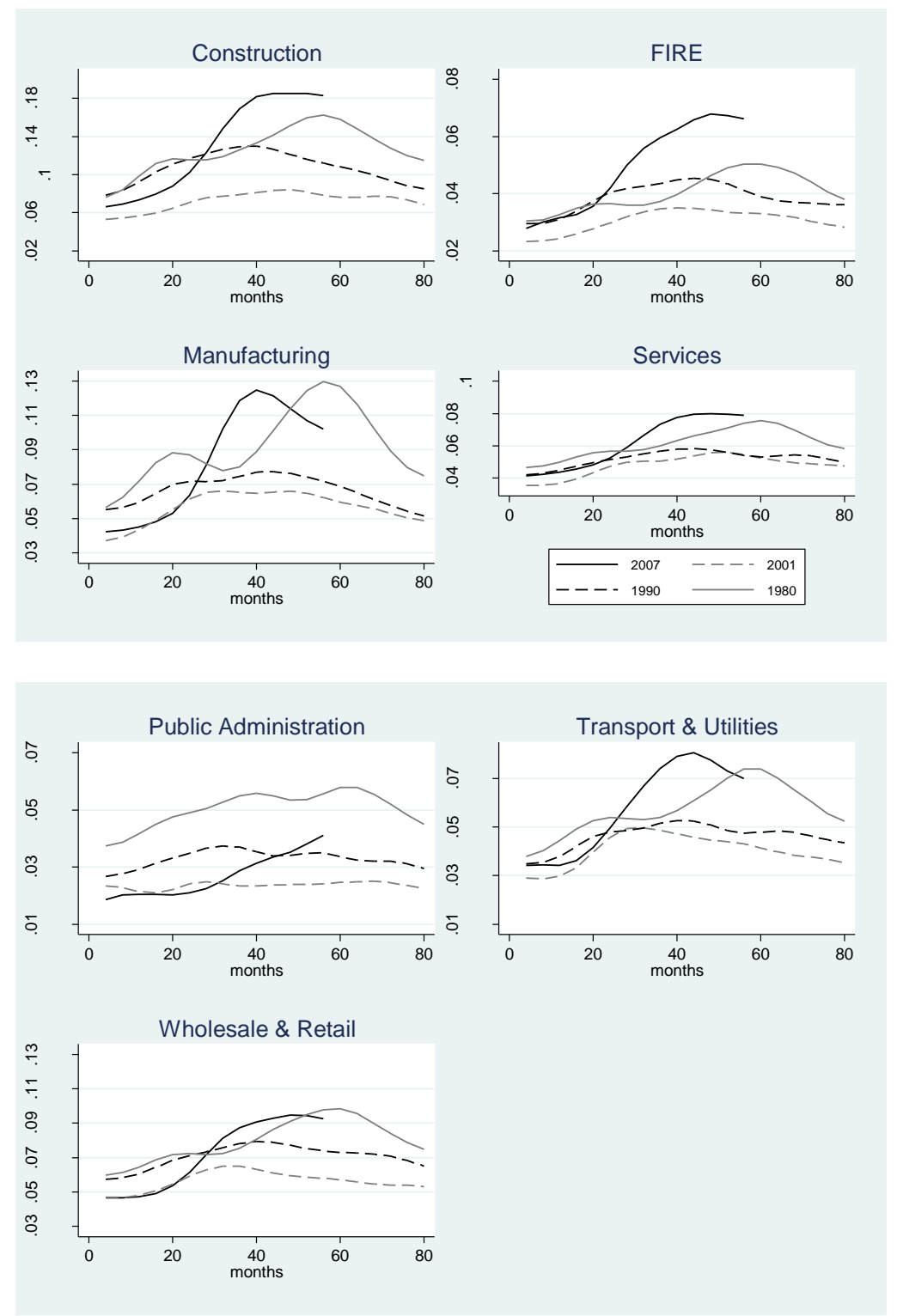

Source: Bureau of Labor Statistics, Current Population Survey. 
Figure 4: The aggregate and industry unemployment rate decline and increase during 1976-2011.

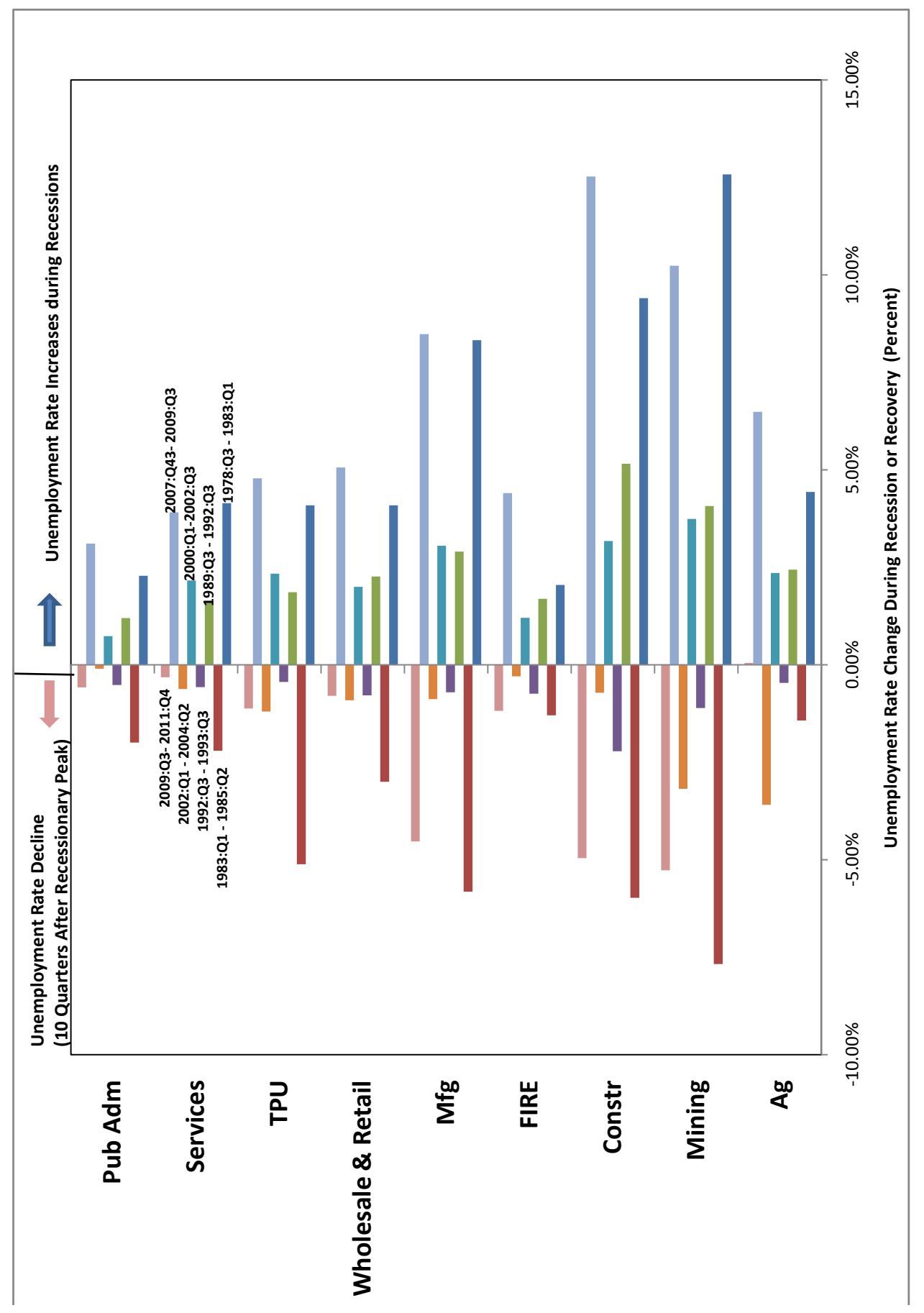


Figure 5: Aggregate flows during 1976-2010.

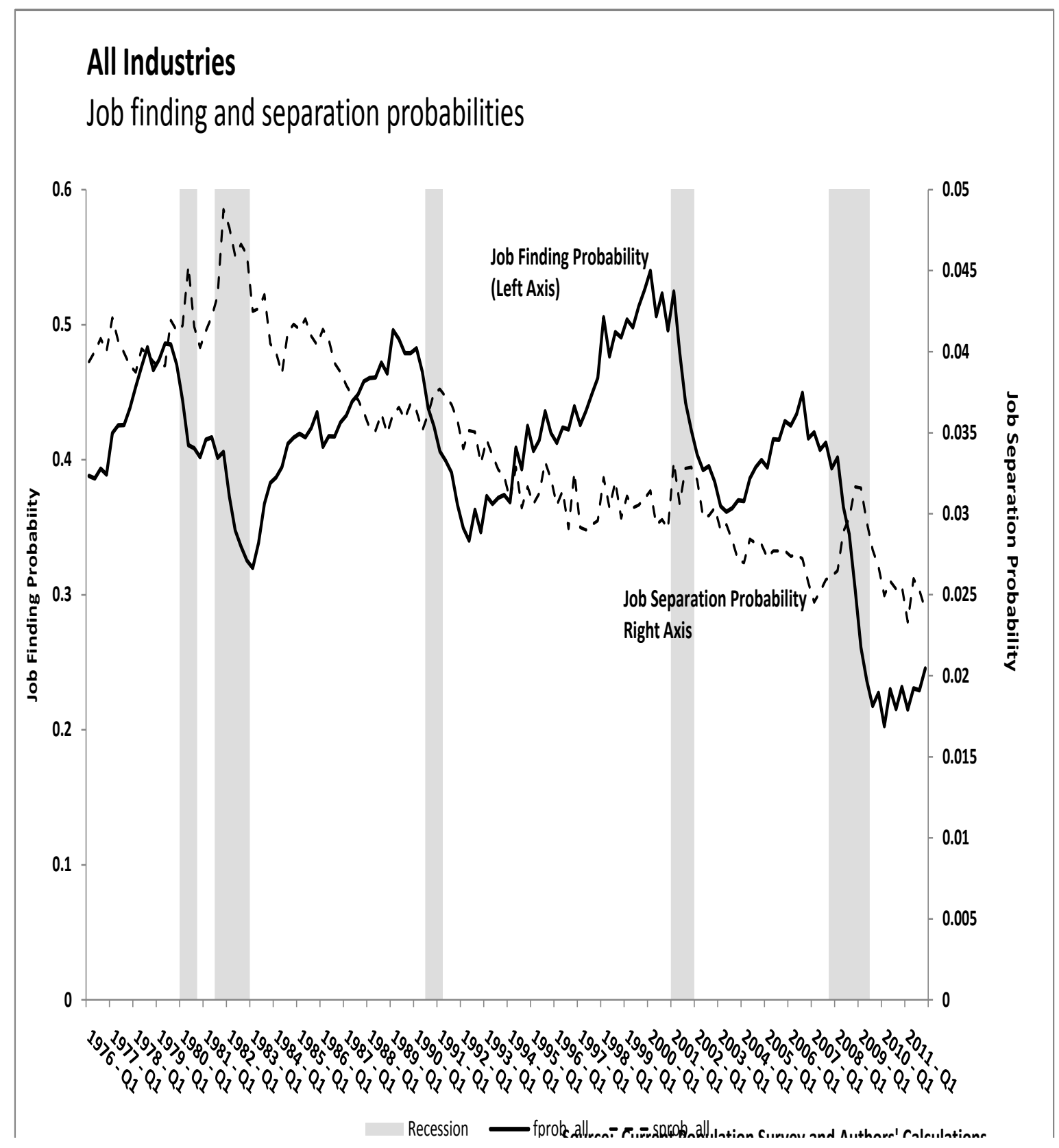

Source: Bureau of Labor Statistics, Current Population Survey. 
Figure 6: Computing Contributions of Job Finding and Separation Rates to the Aggregate Unemployment Rate Increase.

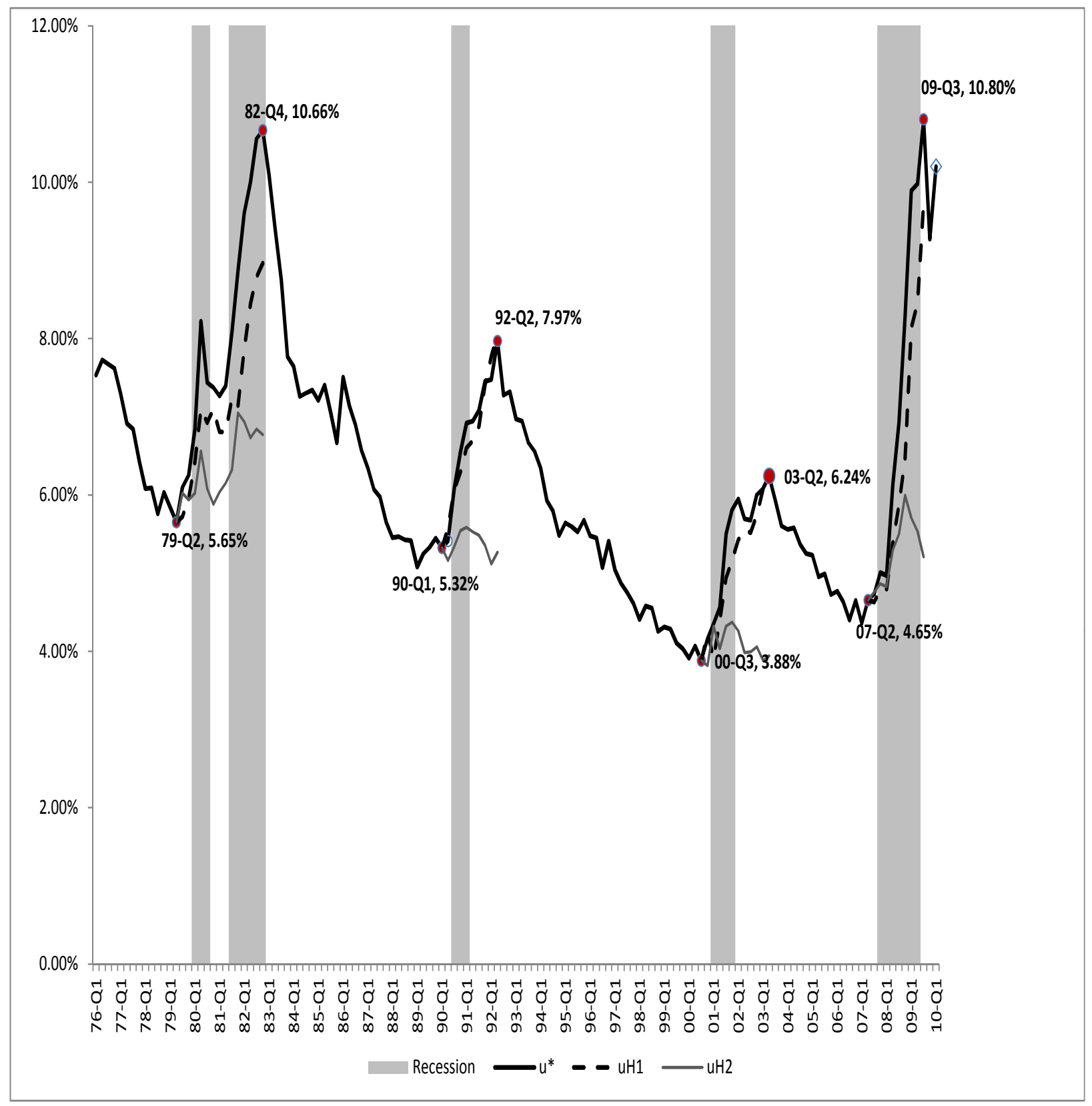

Source: Bureau of Labor Statistics, Current Population Survey. 
Figure 7: Flows contribution to the aggregate unemployment rate (1976-2010).
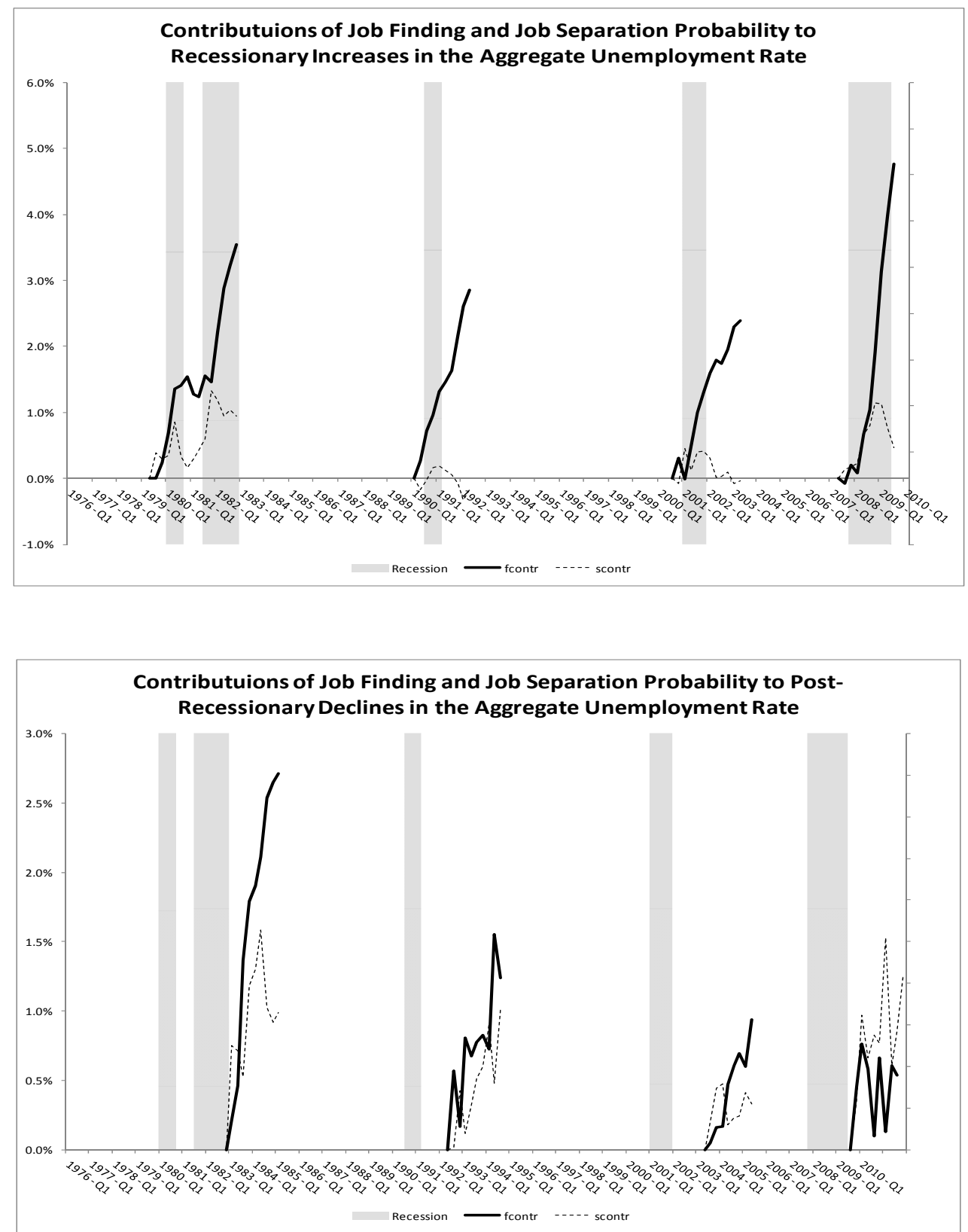

Source: Bureau of Labor Statistics, Current Population Survey. 
Figure 8: Job finding probability by industry during 1976-2011.
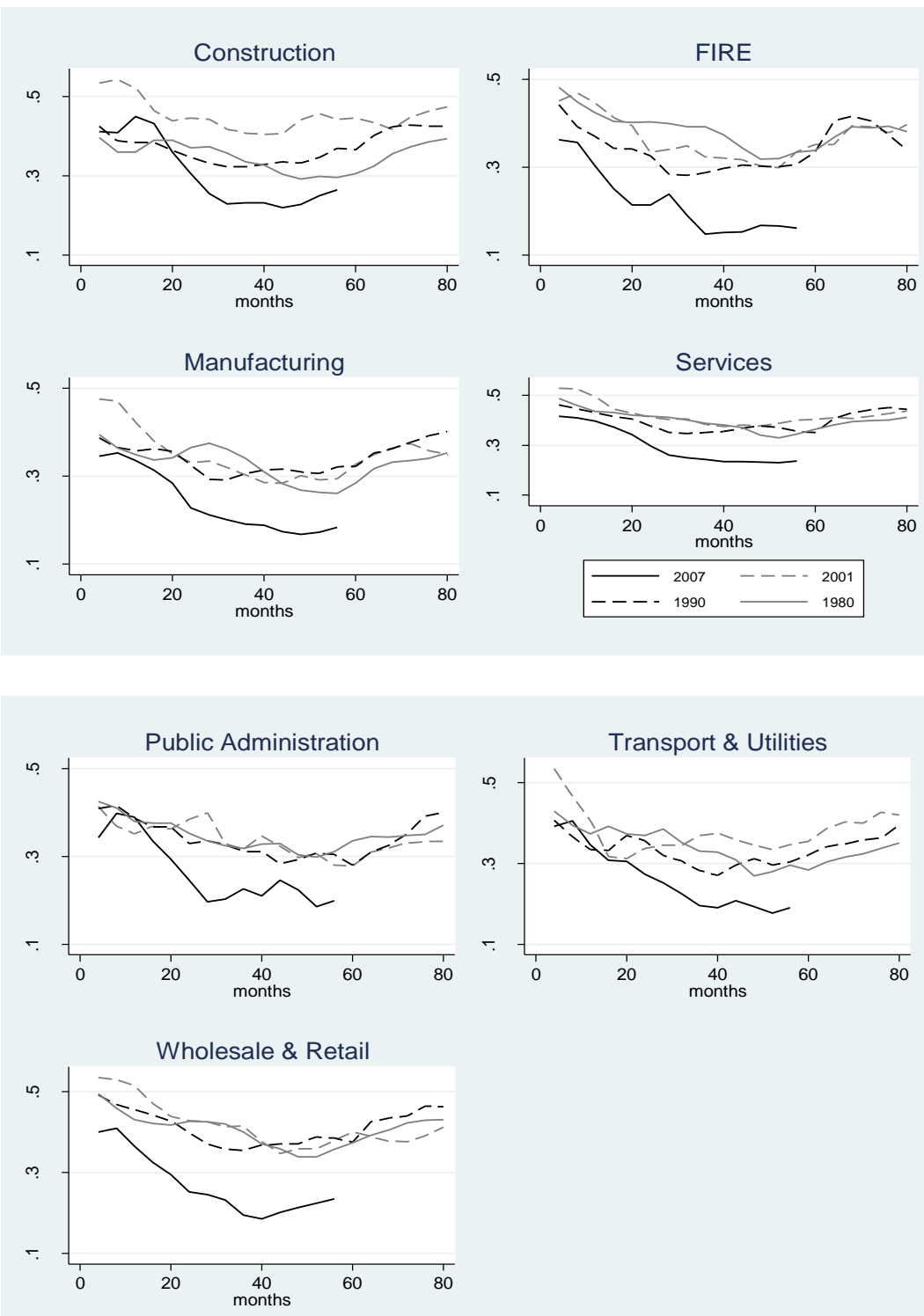

Source: Bureau of Labor Statistics, Current Population Survey. 
Figure 9: Job separation probability by industry during 1976-2011.
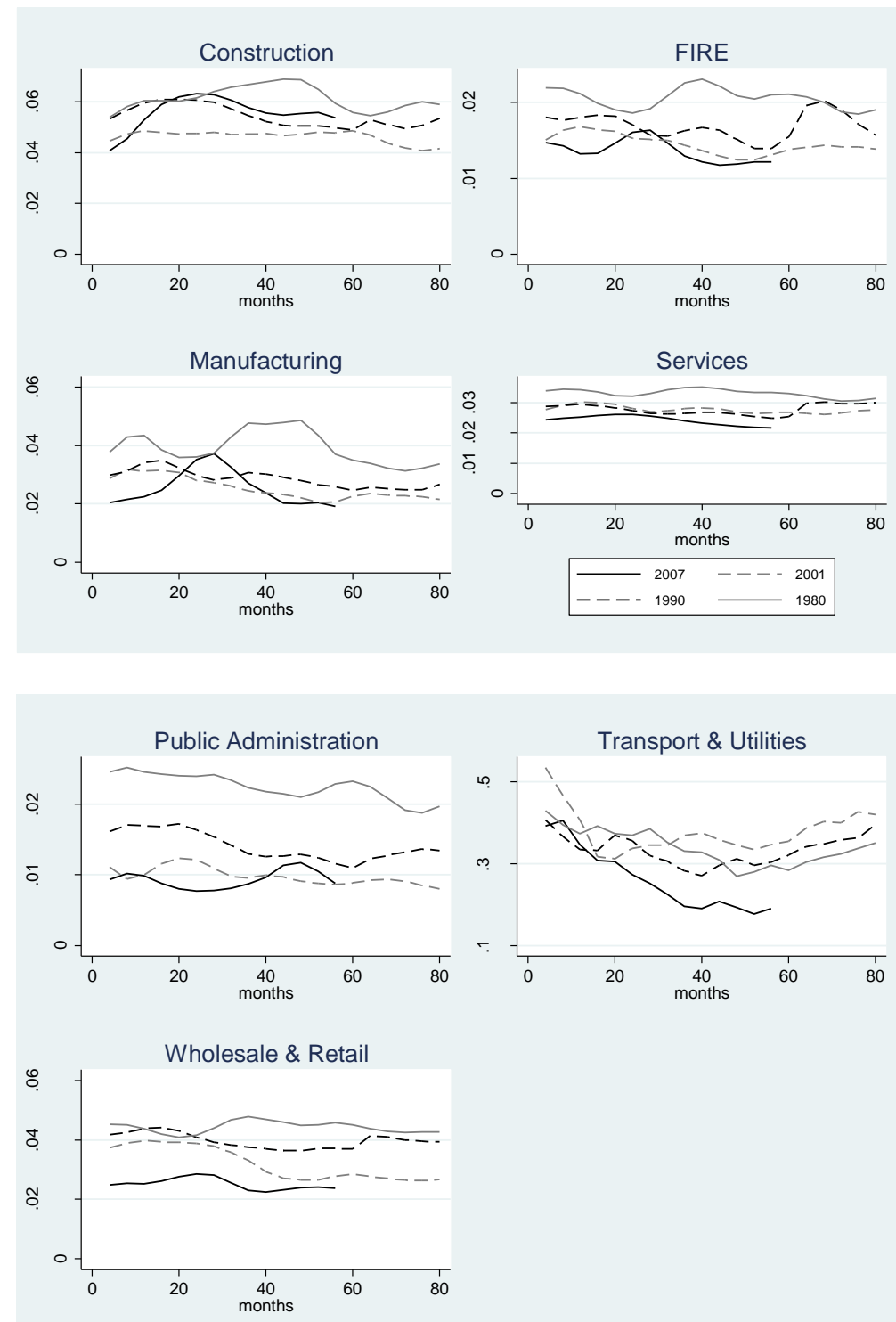

Source: Bureau of Labor Statistics, Current Population Survey. 
Figure 10: Deviation of Industry-specific Job Finding Probability from the Average.
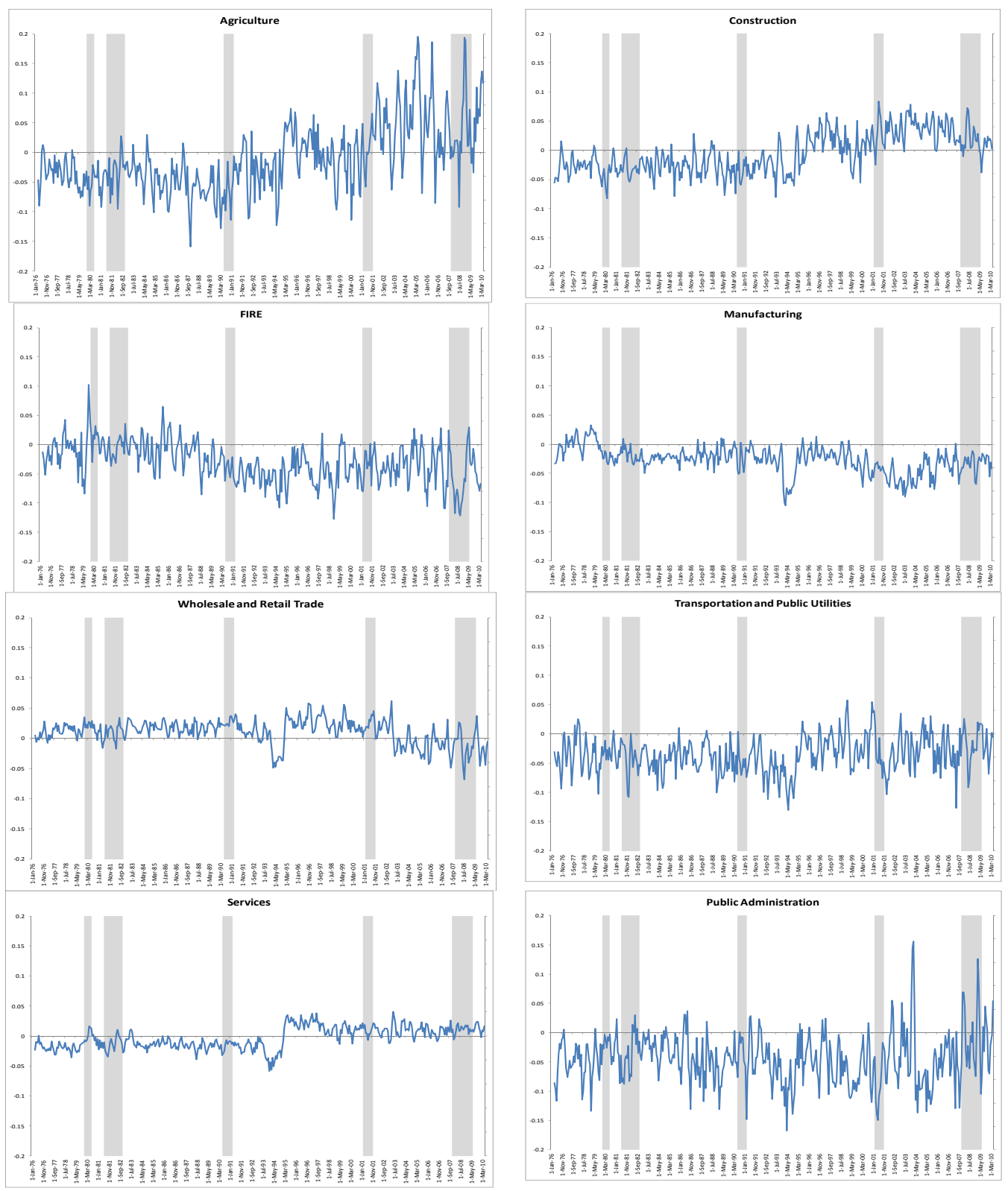

Source: Bureau of Labor Statistics, Current Population Survey. 
Figure 11: Dispersion in Job Finding Probability across Industries.

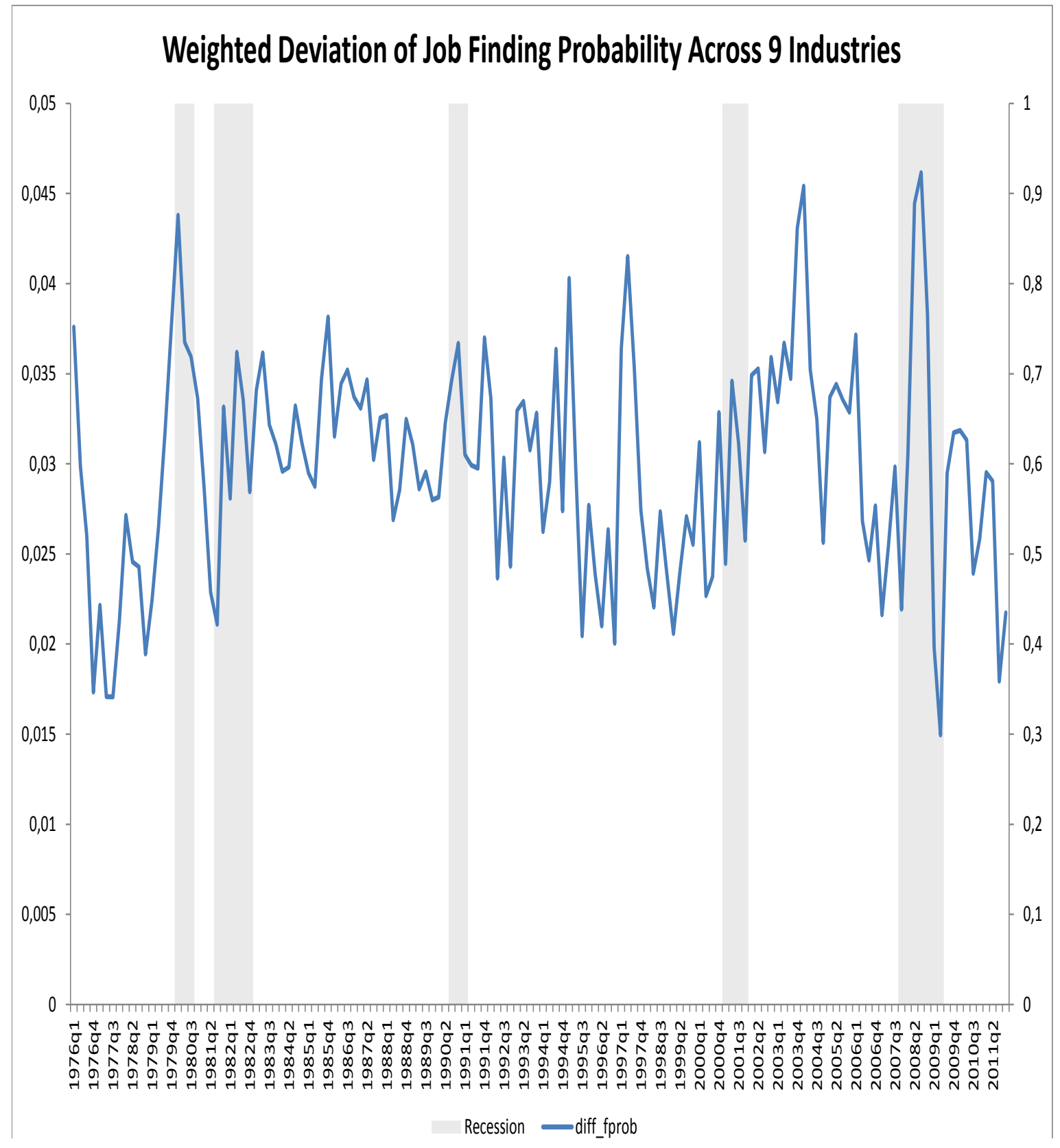

Source: Bureau of Labor Statistics, Current Population Survey. 

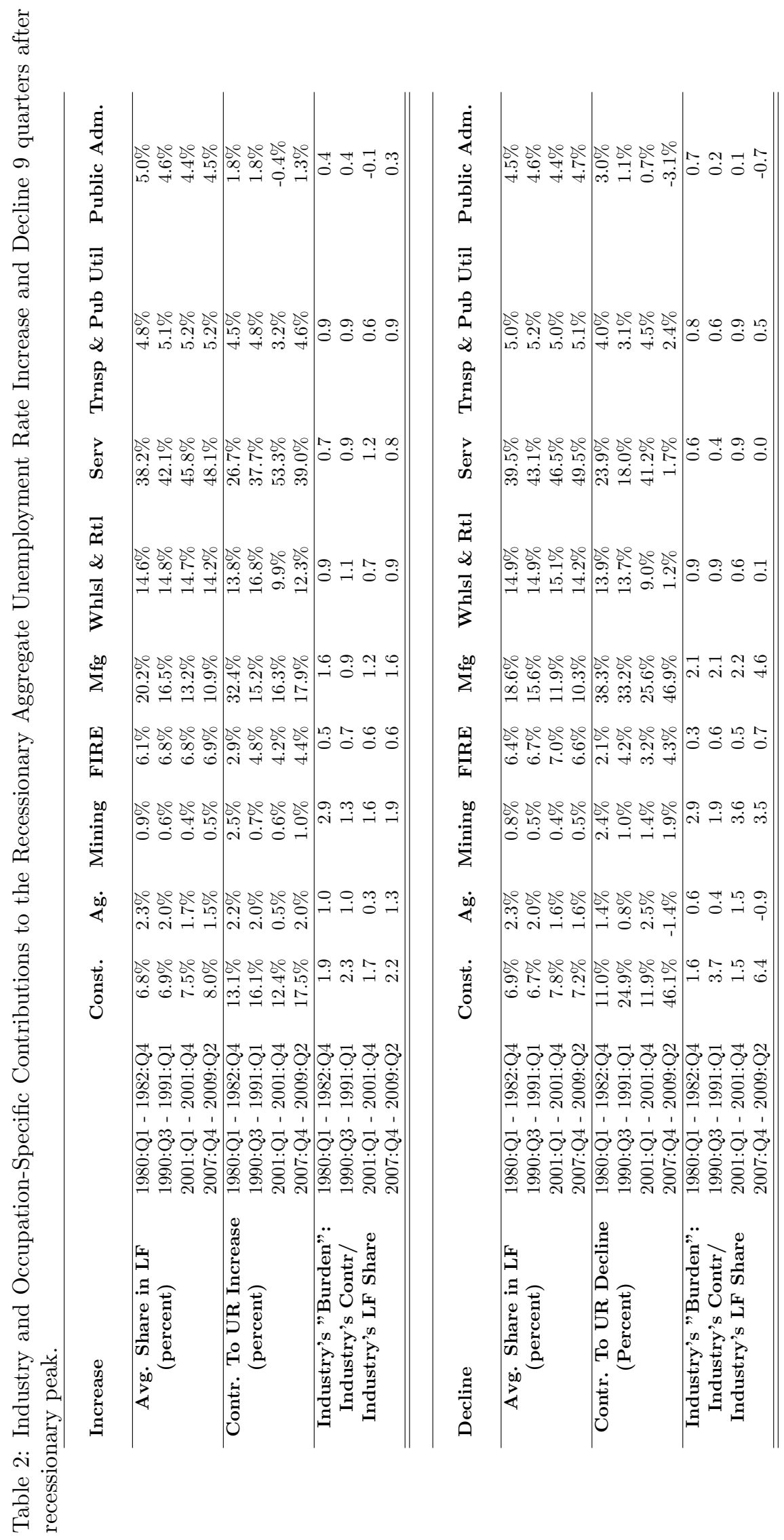
Table 3: Contributions of Industry-Specific Job Finding and Separation Rates to Recessionary Unemployment Rate Increases and Declines (percentage points).

\begin{tabular}{|c|c|c|c|c|c|c|c|c|c|c|}
\hline Increases & \multicolumn{2}{|c|}{ Const } & \multicolumn{2}{|c|}{ Ag } & \multicolumn{2}{|c|}{ Mining } & \multicolumn{2}{|c|}{ FIRE } & \multicolumn{2}{|c|}{ Mfg } \\
\hline Recession & f & $\mathbf{s}$ & f & $\mathbf{s}$ & f & $\mathbf{s}$ & f & $\mathbf{s}$ & f & $\mathbf{s}$ \\
\hline 1980:Q1 - 1982:Q4 & $0.41 \%$ & $0.18 \%$ & $0.08 \%$ & $0.02 \%$ & $0.02 \%$ & $0.10 \%$ & $0.11 \%$ & $0.02 \%$ & $1.04 \%$ & $0.42 \%$ \\
\hline 1990:Q3 - 1991:Q1 & $0.24 \%$ & $0.09 \%$ & $0.04 \%$ & $0.00 \%$ & $0.01 \%$ & $0.00 \%$ & $0.11 \%$ & $-0.02 \%$ & $0.35 \%$ & $-0.04 \%$ \\
\hline 2001:Q1 - 2001:Q4 & $0.20 \%$ & $0.04 \%$ & $0.02 \%$ & $-0.01 \%$ & $0.01 \%$ & $0.00 \%$ & $0.10 \%$ & $-0.02 \%$ & $0.34 \%$ & $-0.02 \%$ \\
\hline \multirow[t]{2}{*}{ 2007:Q4 - 2009:Q2 } & $0.58 \%$ & $0.27 \%$ & $0.04 \%$ & $0.05 \%$ & $0.02 \%$ & $0.03 \%$ & $0.22 \%$ & $-0.01 \%$ & $0.63 \%$ & $0.24 \%$ \\
\hline & \multicolumn{2}{|c|}{ Whls \& Rtl } & \multicolumn{2}{|c|}{ Serv } & Transp & Pub Utl & \multicolumn{2}{|c|}{ Pub Admin } & & \\
\hline Recession & $f$ & $\mathrm{~s}$ & $f$ & $\mathbf{s}$ & $\mathrm{f}$ & $\mathrm{s}$ & $\mathrm{f}$ & $\mathrm{s}$ & & \\
\hline 1980:Q1 - 1982:Q4 & $0.56 \%$ & $0.06 \%$ & $1.08 \%$ & $0.13 \%$ & $0.15 \%$ & $0.05 \%$ & $0.08 \%$ & $0.00 \%$ & & \\
\hline 1990:Q3 - 1991:Q1 & $0.41 \%$ & $-0.07 \%$ & $0.95 \%$ & $-0.18 \%$ & $0.11 \%$ & $-0.01 \%$ & $0.05 \%$ & $-0.01 \%$ & & \\
\hline 2001:Q1 - 2001:Q4 & $0.29 \%$ & $-0.09 \%$ & $0.97 \%$ & $0.08 \%$ & $0.07 \%$ & $0.00 \%$ & $-0.04 \%$ & $0.04 \%$ & & \\
\hline 2007:Q4 - 2009:Q2 & $0.60 \%$ & $0.00 \%$ & $1.86 \%$ & $0.03 \%$ & $0.20 \%$ & $0.03 \%$ & $0.05 \%$ & $0.01 \%$ & & \\
\hline Declines & \multicolumn{2}{|c|}{ Const } & \multicolumn{2}{|c|}{$\overline{\mathrm{Ag}}$} & \multicolumn{2}{|c|}{ Mining } & \multicolumn{2}{|c|}{$\overline{\text { FIRE }}$} & \multicolumn{2}{|c|}{ Mfg } \\
\hline Recession & f & $\mathbf{s}$ & f & $\mathbf{s}$ & f & $\mathbf{s}$ & $\mathrm{f}$ & $\mathbf{s}$ & f & $\mathbf{s}$ \\
\hline 1980:Q1 - 1982:Q4 & $-0.21 \%$ & $-0.13 \%$ & $-0.06 \%$ & $0.02 \%$ & $-0.02 \%$ & $-0.06 \%$ & $-0.06 \%$ & $0.00 \%$ & $-0.75 \%$ & $-0.44 \%$ \\
\hline 1990:Q3 - 1991:Q1 & $-0.23 \%$ & $-0.08 \%$ & $0.00 \%$ & $-0.01 \%$ & $0.00 \%$ & $-0.01 \%$ & $-0.12 \%$ & $0.07 \%$ & $-0.22 \%$ & $-0.18 \%$ \\
\hline 2001:Q1 - 2001:Q4 & $-0.07 \%$ & $-0.05 \%$ & $-0.04 \%$ & $0.01 \%$ & $0.00 \%$ & $-0.02 \%$ & $-0.05 \%$ & $0.01 \%$ & $-0.21 \%$ & $-0.06 \%$ \\
\hline \multirow{2}{*}{$\begin{array}{r}\text { 2007:Q4 - 2009:Q2 } \\
\text { hline }\end{array}$} & $-0.19 \%$ & $-0.29 \%$ & $0.01 \%$ & $0.01 \%$ & $0.00 \%$ & $-0.02 \%$ & $-0.03 \%$ & $-0.01 \%$ & $-0.10 \%$ & $-0.39 \%$ \\
\hline & \multicolumn{2}{|c|}{ Whls \& Rtl } & \multicolumn{2}{|c|}{ Serv } & Transp & ub Utl & \multicolumn{2}{|c|}{ Pub Admin } & & \\
\hline Recession & $f$ & $\mathbf{s}$ & $\mathrm{f}$ & $\mathbf{s}$ & $\mathrm{f}$ & $\mathrm{s}$ & $\mathrm{f}$ & $\mathbf{s}$ & & \\
\hline 1980:Q1 - 1982:Q4 & $-0.38 \%$ & $-0.05 \%$ & $-0.66 \%$ & $-0.09 \%$ & $-0.09 \%$ & $-0.03 \%$ & $-0.08 \%$ & $-0.01 \%$ & & \\
\hline 1990:Q3 - 1991:Q1 & $-0.23 \%$ & $0.07 \%$ & $-0.45 \%$ & $0.23 \%$ & $-0.04 \%$ & $0.00 \%$ & $-0.01 \%$ & $0.00 \%$ & & \\
\hline 2001:Q1 - 2001:Q4 & $-0.08 \%$ & $-0.02 \%$ & $-0.39 \%$ & $-0.05 \%$ & $-0.03 \%$ & $-0.01 \%$ & $0.00 \%$ & $-0.01 \%$ & & \\
\hline 2007:Q4 - 2009:Q2 & $0.00 \%$ & $-0.01 \%$ & $0.00 \%$ & $-0.02 \%$ & $-0.01 \%$ & $-0.02 \%$ & $0.04 \%$ & $0.00 \%$ & & \\
\hline
\end{tabular}


Figure A1: Matched labor force series by industry (2000-2010).
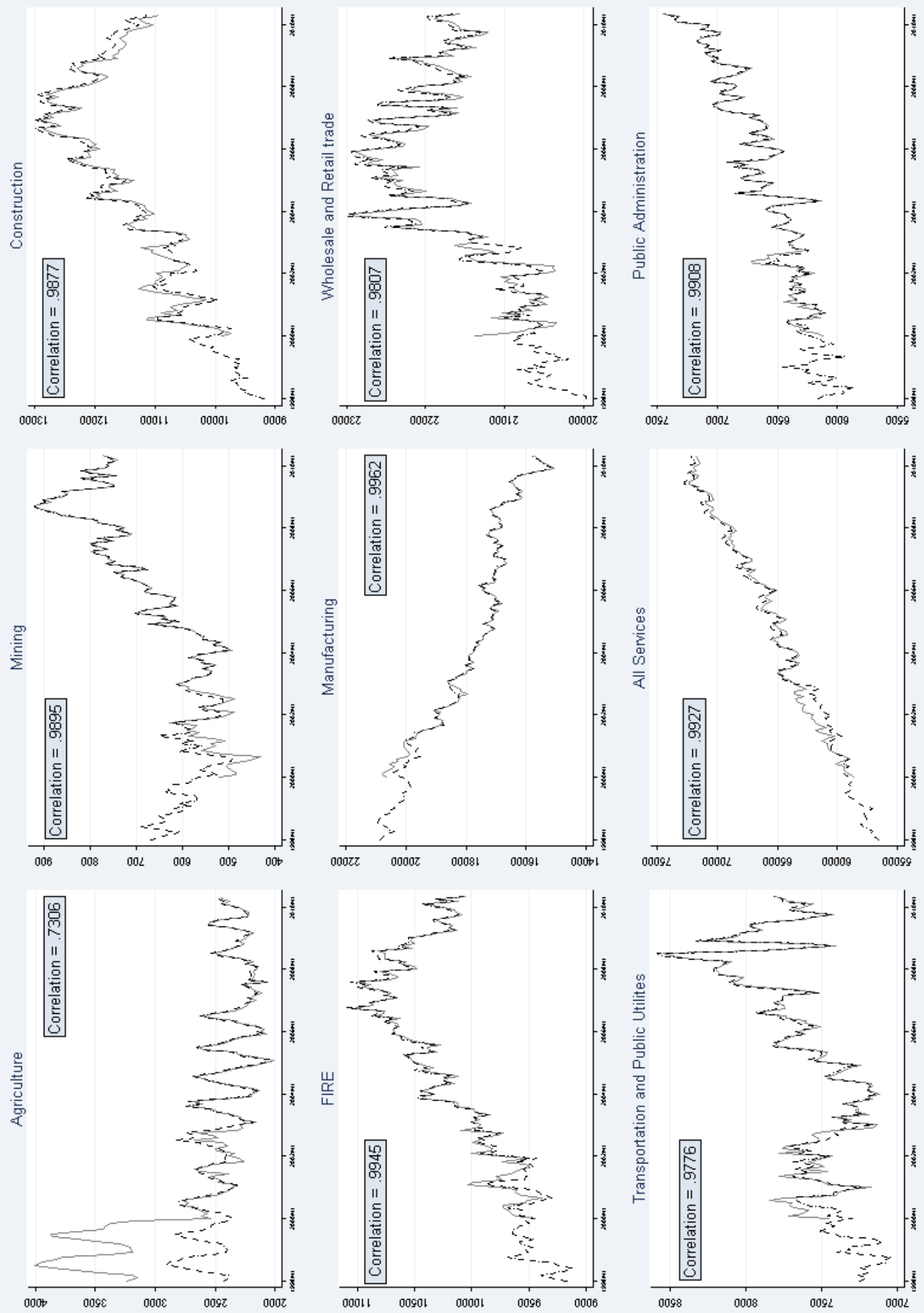

Source: Bureau of Labor Statistics, Current Population Survey.

Note: Sold lines represent the BLS published series. Dashed lines represent the industry labor force series after reclassification. 


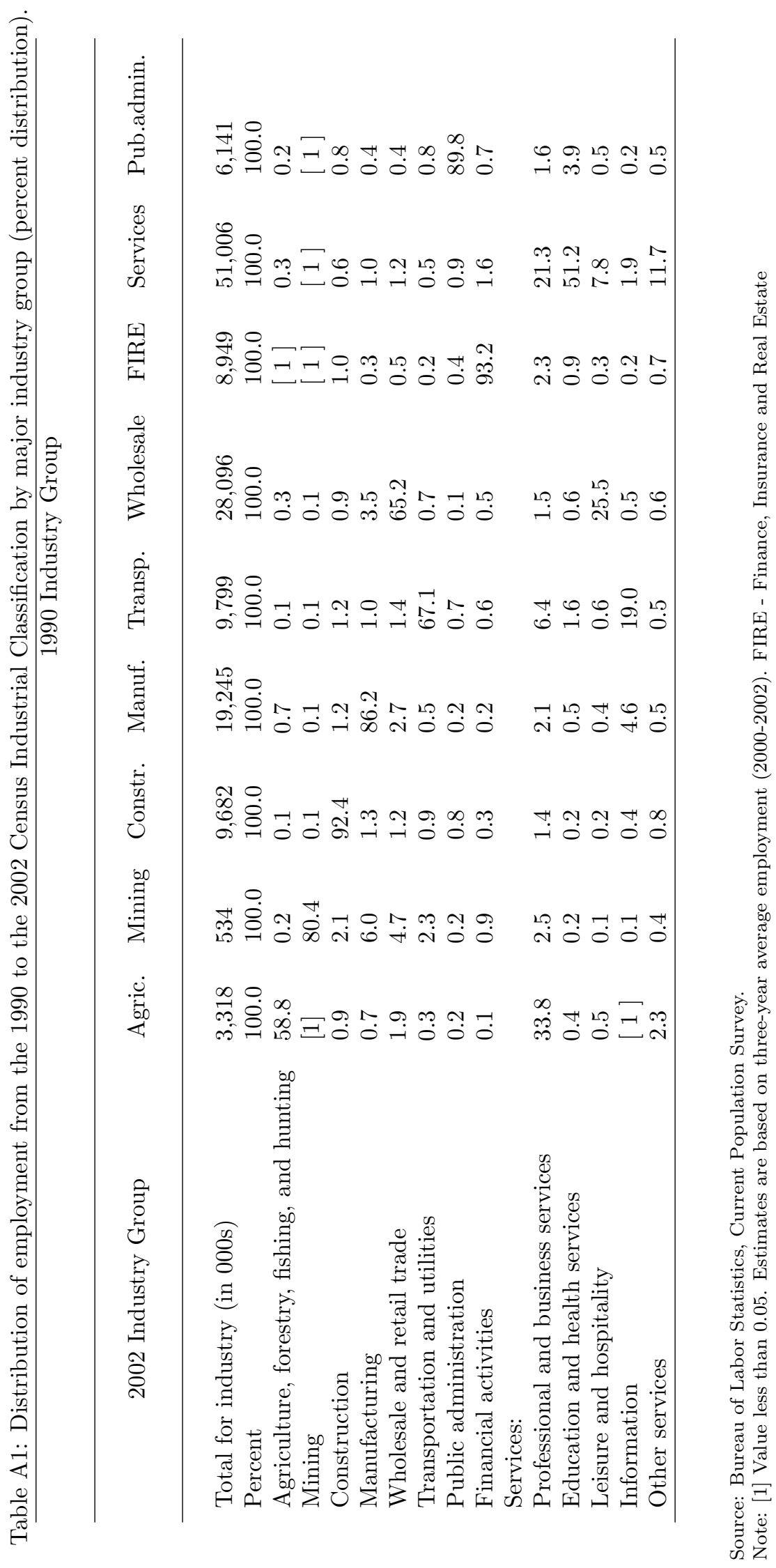

